Board of Governors of the Federal Reserve System

International Finance Discussion Papers

Number 727

May 2002

\title{
INTERNATIONAL COMPARISONS OF PRODUCTIVITY GROWTH: THE ROLE OF INFORMATION TECHNOLOGY AND REGULATORY PRACTICES
}

\author{
Christopher Gust and Jaime Marquez
}

NOTE: International Finance Discussion Papers are preliminary materials circulated to stimulate discussion and critical comment. References in publications to International Finance Discussion Papers (other than an acknowledgment that the writer has had access to unpublished material) should be cleared with the author or authors. Recent IFDPs are available on the Web at www.federalreserve.gov/pubs/ifdp/. 
INTERNATIONAL COMPARISONS OF PRODUCTIVITY GROWTH:

THE ROLE OF INFORMATION TECHNOLOGY AND REGULATORY PRACTICES

Christopher Gust and Jaime Marquez*

\begin{abstract}
While information technologies (IT) are credited with the recent acceleration in productivity in the United States, many other industrial countries have not experienced a pickup in productivity growth. To explain this productivity divergence, we use panel data from 1992 to 1999 for 13 industrial countries and find that this divergence is driven in part by differences in both the production and adoption of information technologies. Based on this finding, we proceed to investigate what factors might play a role in explaining differences in IT adoption. Our results support the view that burdensome regulatory environments and in particular regulations affecting labor market practices have impeded the adoption of information technologies and slowed productivity growth in a number of industrial countries.

We then develop a theoretical model with vintage capital and labor to evaluate the effect of more stringent labor market regulations on a firm'sdecision to adopt new technologies. We establish conditions under which a tax on firing workers delays the adoption of IT technology. These conditions occur when technological change is skill-biased and a firm must upgrade the quality of its workforce through labor turnover. The resulting delay in adopting IT technology then has negative implications for economy-wide productivity and is largely consistent with our empirical results.
\end{abstract}

Keywords: Information Technology, Labor Productivity, Business Regulations, Employment Protection Legislation, International Panel Data.

* Staff economists of the Division of International Finance of the Federal Reserve Board. We presented a preliminary version of this paper at the Board's IF Workshop and at the Spring meeting of the Midwest International Economics Group (Northwestern University, May 2002). We are grateful to seminar participants as well as Brett Berger, Rochelle Edge, Jon Faust, Joe Gagnon, Luca Guerrieri, Dale Henderson, Dirk Pilat, and Dan Sichel for their comments. We thank Vishal Gujadhur for his research assistance. The views in this paper are solely the responsibility of the authors and should not be interpreted as reflecting the views of the Board of Governors of the Federal Reserve System or of any other person associated with the Federal Reserve System. The views in this paper are solely the responsibility of the authors and should not be interpreted as reflecting the views of the Board of Governors of the Federal Reserve System or of any other person associated with the Federal Reserve System. 


\section{Introduction}

In recent years, the United States has experienced an impressive pickup in productivity growth that for the most part has not occurred abroad. ${ }^{1}$ What is remarkable about this development is that the chief explanation for the acceleration in U.S. productivity - the proliferation of computer and information technology - is available worldwide. ${ }^{2}$ Indeed, this divergence in productivity is puzzling given that many industrial countries have many of the same structural and institutional characteristics as the United States such as well-educated workforces, an openness to trade, and well-developed legal frameworks. What, then, explains the failure of productivity growth to pick up in many of these other industrial countries?

This paper provides evidence for a view that can account for this recent productivity divergence between the United States and other industrial countries by emphasizing the role of regulatory practices in influencing the diffusion of information technologies. According to this view, burdensome regulations in various countries, but particularly in a number of European countries, have impinged on firms' incentive to adopt new technologies, slowing their rate of adoption. The delay in the adoption of new technologies in these countries then translates into slower productivity growth vis-à-vis the United States.

With a wide variety of regulatory differences across countries, this view has been expressed in a number of ways. Some proponents focus mainly on product market regulations, specifically those inhibiting competition in goods markets. One variant in this genre, for instance, focuses on regulations raising the cost to entry of new firms. Others focus more specifically on labor-market regulations, specifically those that undermine the ability of firms to adjust their workforce in a flexible manner. One proponent of this view is Greenspan (2000) who argues that in order to reap the high returns associated with information technologies, a firm must be able to reorganize their workforce, and employment protection legislation interferes with a firm's ability to do so:

Europe and Japan have participated in this recent wave of invention and innovation

\footnotetext{
${ }^{1}$ For evidence on this observation, see, for example, Gust and Marquez (2000) or Scarpetta, Bassanini, Pilat, and Schreyer (2000).

${ }^{2}$ See, for example, Gordon (2000), Oliner and Sichel (2000), Jorgenson and Stiroh (2000), and U.S. Council of Economic Advisors (2001).
} 
and have full access to the newer technologies. However, they arguably have been slower to apply them. The relatively inflexible and, hence, more costly labor markets of these economies appear to be an important factor.

Another proponent advocating the importance of labor-market regulations is Feldstein (2001):

In Europe, fundamental changes in employment practices, labor markets and management incentives are necessary to encourage rapid adoption of new technology that can raise productivity while increasing employment. Without such changes, the gap between US and European incomes will continue to widen.

Figures 1 and 2 show that the Greenspan-Feldstein argument is not lacking in empirical support. Specifically, Figure 1 plots the change in labor productivity growth between 1991-1995 and 1996-2000 against the change in the ratio of IT expenditures to GDP between 1992 and 1999. As shown there, countries whose IT expenditures rose sharply in the 1990s also experienced a pickup in productivity growth. In contrast, countries where spending on information technologies fell or only picked up marginally did not experience an acceleration in productivity. Figure 2 plots the ratio of IT expenditures to GDP in 1999 against the index of the level of employment protection in 1998. This index, constructed by the OECD, attempts to measure how much regulations impede a firm's ability to adjust its workforce. As shown there, countries whose level of employment protection is high are the ones with the smallest GDP share of IT expenditures. In contrast, countries with the smallest level of employment protection are those with the highest GDP share of IT expenditures.

Thus, when taken together, the bivariate correlations of Figures 1 and 2 clearly support the explanation posited by Greenspan and Feldstein: countries with the greatest employment protection have the lowest adoption of IT investment and the smallest productivity growth. What is not clear, however, is whether those correlations vanish if one controls for other factors that affect productivity performance and IT investment - a question we address in this paper. 
To do this, we postulate two linear regressions and estimate their parameters with a panel of industrial countries using data over the 1990s. The first relation explains productivity growth in terms of IT expenditures and production relative to GDP controlling for a variety of factors including changes in labor force participation rate, R\&D expenditures, and cyclical influences. The second relation explains the ratio of IT expenditures to GDP using indices on regulations affecting employment and startup costs for new firms, while also controlling for factors such as the level of education, the size of the service sector, and the availability of venture capital. Our results are supportive of the view that burdensome regulations can impede the adoption of information technologies and slow productivity growth. In addition, our results corroborate the Greenspan-Feldstein view that labor market practices can hinder the adoption of information technologies.

To rationalize this finding, we formalize the Greenspan-Feldstein view using a model of vintage capital and labor. In the model, a tax on firing workers can cause a firm to delay its adoption of new technology. This adoption decision is endogenous to a firm, since technology is embodied in capital, and each period a firm decides whether to replace its current vintage of capital and install a new vintage of capital embodying the latest technology. In addition, technological change is skill-biased in the model, as a firm also needs to upskill its labor force in order to utilize the latest technology. Since this upskilling occurs in part through job turnover, higher firing costs cause firms to wait longer to upskill their labor force and adopt the latest technology. As a result, economies with higher firing costs have older, less efficient capital, fewer skilled workers, and a lower level of productivity, on average.

The rest of this paper proceeds as follows. Section 2 discusses the literature related to our empirical analysis. Section 3 then examines the data on productivity growth, IT production and spending, and the regulatory variables of interest. In this section, we also describe the empirical results from our regression analysis. Section 4 then presents the theoretical model of vintage capital and labor, where a tax on firing workers delays a firm's adoption of new technologies. Here, we show the model's implications for investment and productivity for economies with and without a firing tax. Section 5 then concludes. 


\section{Related Literature}

Our empirical results are related to the growing literature exploring the link between developments in the IT sector and labor productivity growth. Previous work explaining the acceleration in productivity in the United States has emphasized two ways that developments in the IT sector benefit labor productivity. The first is that producers of computers, semiconductors, and other high-tech equipment have been making sizeable efficiency gains, boosting aggregate total factor productivity growth. In fact, Gordon (2000) argues that a large part of the improvement in structural productivity in the late 1990s was driven by these gains. The other related channel is that these efficiency gains in the production of IT goods have led to unprecedented declines in prices for these goods, spurring IT-related capital deepening. Oliner and Sichel (2000) and Jorgenson and Stiroh (2000) argue that IT-related capital deepening has played an important role in the acceleration in productivity in the United States. ${ }^{3}$

In an international context, a number of papers have applied the growth accounting framework used by Oliner and Sichel (2000) and Jorgenson and Stiroh (2000) to other industrial countries. ${ }^{4}$ Two papers that use this approach and make cross-country comparisons are Colecchia and Schreyer (2001) and Daveri (2000). Using data for nine industrial countries, Colecchia and Schreyer (2001) find that in the major European countries and Japan, the contribution to growth from IT-related capital deepening has been less important than in the United States and has not increased significantly in the latter 1990s. However, they do find that IT-related capital deepening played a role in the pickup in output growth in Australia and Finland in the 1990s.

Using similar methods but different data, Daveri (2000) also concludes that IT-related capital has played a less important role in a number of European countries than in the United States in the 1990s. ${ }^{5}$ Our work complements the Colecchia and Schreyer (2001) and Daveri

\footnotetext{
${ }^{3} \mathrm{~A}$ third possible way that IT spending may boost productivity is through spillovers either by stimulating business reorganization or by spurring the dissemination of information. However, the macroeconomic evidence to date is inconclusive on the importance of this channel. See IMF (2001) for a discussion of this point.

${ }^{4}$ Two examples are Cardarelli (2001) who examines the Australian data, and Oulton (2001), who uses U.K. data.

${ }^{5}$ Colecchia and Schreyer (2001) use IT investment data from national statistical agencies. Our paper as
} 
(2000) papers by examining the role of IT expenditures in influencing productivity trends in the context of panel regressions. Our empirical analysis largely confirms these earlier results, suggesting that the rate of diffusion of information technologies has been less rapid in many European countries.

Two other related papers are Pilat and Lee (2001) and Roeger (2001). By estimating the contribution of the IT-producing sector to growth in a number of industrial countries, Pilat and Lee (2001) find that the IT-producing sector has made important contributions to growth in Finland, Japan, and Korea. Roeger (2001) also argues that differences in the rate of technological progress in IT production are important in explaining differences in growth between the United States and Europe.

While papers like Pilat and Lee (2001) and Colecchia and Schreyer (2001) explore crosscountry differences in the development of the IT sector, few papers investigate the underlying factors that might explain these differences. An important exception is Caselli and Coleman (2001), who find evidence that computer expenditures are positively associated with levels of human capital. We find similar results in our analysis. However, our focus is on evaluating the view that regulatory practices are an important factor in explaining differences in the adoption of information technology across countries.

\section{Empirical Analysis}

Our empirical analysis begins by examining the cross-country data on labor productivity growth in the 1990s. We then turn to addressing the question of whether developments in the IT sector help explain the cross-country variation of labor productivity growth in the 1990s. Next, we turn to addressing the role of regulations in explaining cross-country differences in the adoption of information technologies. Finally, we conclude this section by examining the sensitivity of our results to alternative modelling specifications.

well as Davari (2000) use data collected by the International Data Corporation (IDC) on IT expenditures by households, firms, and the government sector. While there are reasons to prefer the official data, our decision to use the IDC data reflects the limited number of countries for which the official data are available. 


\subsection{Examining Labor Productivity}

In this section, we present the results documenting the recent divergence in productivity growth between the United States and other industrial countries. To do this, we use labor productivity growth, calculated as $\widehat{\pi}_{t}=\widehat{y}_{t}-\widehat{l}_{t}$ where $\widehat{\pi}$ represents the growth rate of labor productivity, $\widehat{y}$ represents the growth rate of output, and $\widehat{l}$ represents labor input growth. The measure of $y$ used here corresponds to the OECD's definition of business sector value added in real terms. The main difference between this measure and GDP is that business-sector value added nets out the general government sector. The measure of $l$ corresponds to business sector employment adjusted by hours per worker. ${ }^{6}$

Table 1 shows our estimates of labor productivity growth for thirteen industrial countries from 1981-2000. The results indicate that U.S. labor productivity growth was below labor productivity growth in every other country we examined during the 1981-95 period. However, this situation was largely reversed in the latter half of the1990s: Labor productivity growth in the United States was higher than that in all of the other G-7 countries and many of the smaller economies as well. The third column of table 1 embodies this divergence: all countries except the United States, Australia, and Sweden fail to show an acceleration in labor productivity.

In examining Table 1, one question that comes to mind is whether the failure of measured average productivity to accelerate in the 1990s is merely an artifact of the periods chosen to make the growth comparisons. To evaluate this possibility, Figure 3 shows annual growth rates of labor productivity as well as four-year moving averages of these growth rates for the countries in our study. These series make it clear that for most industrial countries, it is impossible to identify a point at which productivity growth started to move up on a sustained basis, as in the United States.

Another possibility is that this result is sensitive to our measure of productivity. However, as discussed in Gust and Marquez (2000), these results also hold for total factor productivity. In

\footnotetext{
${ }^{6}$ For a more detailed discussion of our productivity measure, see Gust and Marquez (2000) or Scarpetta, Bassanini, Pilat, and Schreyer (2000). As argued in Gust and Marquez (2000), it is important to account for changes in hours worked, since there has been a marked decline in the number of hours worked per employee in a number of industrial countries over the past twenty years.
} 
addition, this failure of productivity growth to pick up in the 1990s in most industrial countries is evident in measures of productivity for the manufacturing sector as well. ${ }^{7}$ Thus, with few exceptions, there is little evidence of improved productivity performance, to date, outside of the United States.

\subsection{Explaining International Differences in Productivity Growth}

In principle, a variety of factors could explain why measured productivity has failed to accelerate in most industrial countries. In this paper, we are primarily interested in evaluating the importance of the IT sector in accounting for this divergence in international productivity. To do this, we first examine the importance of a country's IT sector in explaining cross-country differences in productivity growth.

\subsubsection{Data}

We use two different measures to capture the importance of a country's IT sector. The first measure is a country's IT production as a share of GDP. We include this variable in our analysis since productivity gains in this sector in recent years in the United States have been impressive enough to make a large enough impact on overall productivity, despite being only a relatively small fraction of overall production. For example, Oliner and Sichel (2001) estimate that the computer and semiconductor industries accounted for roughly half of their estimate of total factor productivity growth in the late 1990s, although these sectors' shares of total output are only 2.5 percent in the United States.

We construct our measure of IT production using data from the OECD's 2001 STAN database. While this database does not permit disaggregated measures of the production of computers, semiconductors, software, and communication equipment, it does allow us to construct an annual time series of IT production from 1991-1998, where IT production is defined as the production of office and computing equipment as well as radio, television, and communication equipment. Figure 4 plots the value of this series for the 1991-94 and 1995-98 periods

\footnotetext{
${ }^{7}$ See Bureau of Labor Statistics (2000) or Pilat and Lee (2001).
} 
for these countries. As shown there, Finland and the United States have relatively high IT production shares that have risen in the latter 1990s, while Australia and Italy are examples of countries where IT production is small and has declined in the 1990s.

The other measure of the IT sector that we use in our analysis is the ratio of spending on information technologies to GDP. Our measure of expenditures on information technologies is based on data published and collected by the World Information Technology Service Alliance (2001) and the International Data Corporation. This data measures spending on computer hardware, software, telecommunications and other peripheral equipment and are observed annually from 1992-1999. Figure 5 shows these data for the countries in our study for both the early 1990s and late 1990s. As shown there, two countries that have experienced large increases in IT spending from a relatively high level are the United States and Sweden. In contrast, Italy and Spain spend relatively little on information technologies and did not experience much of an increase in the late 1990s.

\subsubsection{Empirical Formulation}

While our goal is to examine the importance of the IT sector in explaining cross-country differences in productivity growth, it is important to control for other factors that influence productivity growth. In our analysis, we attempt to control for a variety of forces influencing labor productivity growth including cyclical factors, $R \& D$ expenditures, and capital deepening in other investment goods.

One factor that we find to be important in influencing labor productivity growth in the 1990s is the change in a country's employment to population ratio. As in Beaudry and Collard (2000), we find that there is a strong negative association between productivity growth and this variable across industrial countries in the 1990s. Using an endogenous growth model, Beaudry and Collard (2000) argue that countries with higher labor force growth are less able to take advantage of the arrival of new technologies. While such an explanation is one possibility, it may also reflect labor market reforms in the 1990s in a number of industrial countries that improved the price of labor relative to capital as well as brought less skilled workers back into 
the labor force.

The regressions we use to evaluate the importance of the IT sector are

$$
\widehat{\pi}_{i t}=\alpha_{i}+\alpha_{1} I T P_{i, t-2}+\alpha_{2} I T_{i, t-1}+\alpha_{3} \widehat{L P}_{i t-1}+\alpha_{4} X_{i t-1}+u_{i t}
$$

where $i=1,2, \ldots, 13, t=1993,1994, \ldots, 2000$, and ITP is the GDP share of IT production, IT is the ratio of IT expenditures to GDP, and $\widehat{L P}$ is the change in the employment to working age population ratio, and $X$ is another control variable such as the output gap or GDP per capita. We allow for fixed country-effects, $\alpha_{i}$, to capture systematic differences across countries that may influence labor productivity growth. Note that the modelling of $\widehat{\pi}_{i t}$ relies on lagged values of the explanatory variables in part due to our desire to rule out the possibility of reverse causality - that shocks to productivity influence the IT sector. However, it also reflects that the productivity data are for 1993-2000, while the IT production variable is only available through 1998 and the IT expenditure variable to 1999.

We estimate this equation using ordinary least squares (OLS) and compute "robust" standard errors. Specifically, for the disturbance terms, we follow Arellano (1987) and allow that $E\left(u_{i t} u_{i s}\right)=\omega_{i t s}>0$ and $E\left(u_{i t} u_{j s}\right)=0$ for $i \neq j$ when computing the standard errors to our OLS estimates. This assumption allows for arbitrary patterns of serial correlation and heteroskedasticity for each country but not across countries. ${ }^{8}$

\subsubsection{Empirical Results}

Table 2 reports our coefficient estimates from this regression. The first column of Table 2 reports our coefficient estimates for our baseline specification for labor productivity growth. As indicated there, increases in IT expenditures and the size of the IT production sector have a positive and significant effect on productivity growth, even when we control for changes in the labor force participation rate.

The rest of the columns in Table 2 show the regression results from expanding this baseline specification to include different control variables, $X_{i t-1}$, one variable at a time. For $X_{i t-1}$ we

\footnotetext{
${ }^{8}$ We use PcGive 10.1 (with the DPD package) and select the "robust" standard errors option; see Doornik and Hendry (2001).
} 
consider the GDP share of overall investment, the output gap as defined by the OECD, the level of per-capita GDP, R\&D expenditures as a percentage of GDP from 1991-98, and the GDP share of government expenditures. We include the overall investment share in the regression to proxy for changes (either cyclical or secular) in the overall capital stock in an economy, while we use the output gap to also control for cyclical factors. The R\&D expenditures variable is intended to capture changes in the resources devoted toward developing new technologies.

To see if a country's initial level of wealth is important, we also use GDP per capita from 1983-1990 as a control variable. This variable should be negative and significant, if the phenomenon commonly referred to as 'catch-up' is important. Finally, we use government expenditures to proxy for the degree of government involvement in an economy. In the appendix, we define these variables more thoroughly and list our sources.

According to the results, the coefficient estimate for the GDP share of IT production is robust to the inclusion of the additional variables: the estimate is nearly always significant at the 5 percent level and it ranges from 0.9 to 1.1, which is a narrow range of variation. The estimates for IT expenditures, while generally significant at the 10 percent level, are not as robust as the estimates for IT production. Specifically, the significance deteriorates when we include the output gap or the GDP share of total investment. Finally, we also test the hypothesis that the IT variables are jointly significant and find that they are in all instances.

The results from Table 2 suggest that the IT sector is an important factor in explaining cross-country differences in productivity growth in the 1990s. However, it is possible that this conclusion is altered when we consider alternative specifications to equation (1) that allow for fixed year-effects as well as correlated productivity disturbances across countries. Later, we evaluate the robustness of our conclusions to these alternative model specifications in our sensitivity analysis. ${ }^{9}$

\footnotetext{
${ }^{9}$ Another possibility is that our results are biased due to differences in national accounting procedures in measuring output. In particular, countries that do not use hedonic price indexes for computer equipment tend to understate output and therefore labor productivity growth relative to countries where such methods are used. However, Schreyer (2001) finds that the effect of this difference on GDP across G7 countries is small.
} 


\subsection{Explaining International Differences in IT Spending}

The results from Table 2 suggest that IT expenditures may be an important factor in explaining cross-country differences in productivity growth in the 1990s. This observation and the view that burdensome regulatory environments have impeded the adoption of information technologies in some industrial countries leads us to investigate what factors influence IT spending across countries. To do this, we use the same strategy as we adopted for explaining productivity growth by considering the effect of different regulatory variables, while also controlling for other factors that may influence IT spending.

\subsubsection{Data}

The regulatory variables that are the focus of our analysis are the index of employment protection legislation (EPL) discussed in the introduction, an index of regulatory burdens on startups (RBS), and an index on overall regulatory burdens (RB). As mentioned in the introduction, the EPL index is constructed by the OECD, who examined legislation on severance pay, procedures for dismissal, and rules involving the use of temporary workers and ranked countries on the restrictiveness of this legislation. The other two regulatory variables, the RBS and RB index, are based on executive-opinion surveys from the World Competitiveness Report 1993 and Global Competitiveness Report 1998. The RBS index attempts to quantify the extent to which administrative procedures are a hindrance to starting a new business, while the RB index measures the pervasiveness of burdensome administrative regulations in general.

Figure 6 shows the regulatory variables for the early and late 1990s. Here, we have standardized each of the variables so that zero corresponds to the least restrictive legislation while six corresponds to the most restrictive legislation. As shown in the top panel of Figure 6, the United States, Canada, the United Kingdom, and Australia have relatively unrestrictive employment protection legislation, while Portugal, Italy, and Greece have the most restrictive legislation. The United States and the United Kingdom both score low in terms of the RBS variable, while Finland and New Zealand score low in terms of the RB variable. In contrast, France and Italy both have relatively pervasive regulatory environments as well as burdensome 
administrative procedures for startups.

\subsubsection{Empirical Formulation}

While considering the importance of these regulatory variables on spending on information technologies, we control for a number of factors. Two factors that are important are years of schooling and the size of a country's service sector. The fact that different industries use information technologies more intensively than others has been noted in Stiroh (2001) and Van Ark (2001). A number of services are particularly heavy users of information technologies, including telecommunication services, finance and insurance, and retail and wholesale trade. The other control variables that we consider include the availability of venture capital, trade openness, and the ratio of overall investment to GDP. In the appendix, we give a more detailed description of these variables as well as a list of our sources.

The regressions we use to evaluate the importance of regulations in influencing IT spending take the form,

$$
I T_{i t}=\beta_{0}+\beta_{1} Y S_{i t}+\beta_{2} S S_{i t}+\beta_{3} R B_{i t}+\beta_{4} R V_{i t}+\beta_{5} X_{i t}+v_{i t}
$$

where $i=1,2, \ldots, 21, t=1992-95,1996-99$, and $Y S, S S$, and $R B$ denote years of schooling, the share of service sector employment to total employment, and the index of regulatory burdens, respectively. ${ }^{10}$ The variable, $R V$, denotes either the RBS or EPL indexes, so that equation (2) allows us to examine the importance of either one of these specific regulatory variables while also controlling for the pervasiveness of regulations in general. Also, $X_{i t}$ is another control variable such as an index on the availability of venture capital or an index of trade openness. The fact that $t$ can take on only two values reflects the limited number of observations we have for some of the independent variables. ${ }^{11}$ As a result of this limitation, unlike equation (1), we do not include country-fixed effects and simply consider pooled regression estimates

\footnotetext{
${ }^{10}$ The IT measure used in this regression differs slightly from the one used in equation (1). Here, the IT measure includes spending on IT services as well as hardware and solftware spending. Our results regarding regulations are robust across these different measure of IT spending. However, the years of schooling variable is no longer significant at the 10 percent level across the different control variables, $X_{i t}$, with IT spending defined using only hardware and software spending.

${ }^{11}$ In particular, we have observations on the EPL and years of schooling variables only in 1990 and 1998.
} 
for equation (2). ${ }^{12}$ In estimating, equation (2), we again use OLS and compute White (1980) heteroskedasticity-corrected standard errors.

\subsubsection{Empirical Results}

Table 3 reports our coefficient estimates from the regressions which include EPL as the sector specific regulatory variable, while Table 4 reports them when RBS is the sector specific regulatory variable. The third column of Table 3 shows the results of our baseline EPL regression that does not include $X_{i t}$. From this regression, we can see that the years of schooling variable and size of the service sector both have a positive and highly significant effect on IT spending.

Both the RB and EPL variables have a negative effect on IT spending but only the EPL variable is significant at the 10 percent level. However, as shown in the bottom of Table 3 we can reject the null that $\beta_{3}=\beta_{4}=0$ at the 5 percent level. Thus, our baseline EPL regression suggests that a burdensome regulatory environment has impeded the adoption of information technologies and that employment protection legislation has an effect that can be distinguished from other regulations.

Columns (4)-(11) of Table 3 consider the addition of other control variables, one variable at a time. From these results, we can see that the years of schooling and the size of the service sector variables are always significant with little variation in their coefficient estimates. In addition, as indicated by the joint test, the regulatory variables have a significant impact on IT expenditures across the different specifications in Table 3.

Additionally, in most specifications, the index on employment protection legislation is significant at the 10 percent level. The major exception to this result is when we include all three regulatory variables. In this case, it becomes difficult to distinguish an independent effect arising from restrictive labor market practices, possibly due to the fact that we do not have enough observations to discriminate between the different types of regulations.

While Table 3 is useful for examining whether the EPL variable has an independent effect on IT spending, we also investigated whether the RBS index had a distinct effect. Table 4 shows

\footnotetext{
${ }^{12}$ This also limits our ability to jointly estimate equations (1) and (2) and exploit their interdependency.
} 
the effects of including this variable across the different regression specifications. As in Table 3 , the regulatory variables together are nearly always jointly significant. Also, similar to the EPL variable, the RBS index is significant at the 10 percent level in most specifications.

\subsection{Sensitivity Analysis}

In this section, we examine the sensitivity of the regression estimates of equations (1) and (2) along several dimensions. With regard to (1), we consider alternative fixed effect models as well as the possibility that the disturbances are correlated across countries. We also estimate equation (2) using instrumental variables to account for the possibility that the widespread use of information technologies throughout the economy may influence an individual's educational choices as well as the size of the service sector. We then estimate equation (2) allowing for the disturbances, $v_{i t}$, to be correlated across the two time periods. We do this since it may be the case that countries whose IT expenditures are higher/lower than predicted by (2) in the early 1990s are also higher/lower in the late 1990s. Finally, we examine whether the factors that affect IT spending are unique to spending on information technologies or whether they are important in affecting investment in other goods.

Our sensitivity analysis begins by examining alternatives to equation (1). In particular, equation (1) only allows for country fixed-effects whereas there is no reason a priori to not include year fixed-effects. Table 5 shows the regression results for the variables included in the baseline specification of (1) but allows for four possible types of fixed effects. Inspection of the results suggests that the coefficient estimates for the IT variables are quite sensitive to the nature of these fixed effects as reflected in the large range of point estimates for these variables.

This finding raises the question of which variant of fixed effects is the relevant one. We address this question by implementing log-likelihood ratio tests. As shown at the bottom of Table 5, excluding country fixed-effects from the specification (columns 3 and 4) leads to a significant decline in the equation's explanatory power. This finding suggests that country fixed-effects should be part of the specification but it does not rule out the possibility of also including year fixed-effects. So, the question becomes what are the gains from including year 
effects. Inspection of the log-likelihood indicates that the inclusion of year fixed-effects (column 3) brings a minimal gain relative to the alternative of no year fixed-effects (column 2). However, the inclusion of year fixed-effects lowers the precision of the point estimates by using degrees of freedom. Thus, on the basis of this finding, we exclude year fixed-effects from the regression.

While we have accounted for the influence of serially-correlated disturbances in equation (1), it could also be the case that the disturbances to productivity growth are correlated across countries. To account for this, we categorize the countries in our sample into two groups: European (EU) and non-European (ROW). We then allow for a common variance, $\sigma_{k}^{2}$, and covariance, $\theta_{k}$, for countries in group $k$ as well as a common covariance, $\theta_{E U, R O W}$ for two countries in different groups. For this case, we assume that the disturbances are independent across time. ${ }^{13}$

Table 6 reports our generalized least squares (GLS) for equation (1) for two different ways of categorizing the European countries. The first grouping (GLS-1) is a geographic one where the European group includes all countries in our 13 country sample except the United States, Canada, Australia, and Japan. The second one (GLS-2) includes only those countries participating in the European Monetary Union - Germany, France, Italy, Spain, the Netherlands, and Finland - as the EU group. As indicated by Table 6, even when we account for correlated disturbances across countries, the IT variables still have a positive and significant effect on productivity growth.

So far, with regard to equation (2), we have taken the view that the regulatory variables and other controls are exogenous to the decision to invest in information technologies. While this view seems reasonable for the regulatory variables, it is possible that the other significant controls - years of schooling and size of the service sector - are influenced by developments in the IT sector. For instance, an individual may seek additional years of schooling in order to become a software designer or other professional whose skills complement information technologies. If this is the case, then our estimates even for the regulatory variables may be biased.

To deal with this endogenity issue, Table 7 reports estimates of the baseline regressions

\footnotetext{
${ }^{13}$ Formally, this specification is $E\left(u_{i t} u_{i t}\right)=\sigma_{k}^{2}$ for $i \in k, E\left(u_{i t} u_{j t}\right)=\theta_{k}$ for $i \neq j$ and $i, j \in k, E\left(u_{i t} u_{j t}\right)=$ $\theta_{E U, R O W}$ for either $i \in E U$ and $j \in R O W$ or $j \in E U$ and $i \in R O W$, and $E\left(u_{i t} u_{j s}\right)=0$ otherwise.
} 
using average years of schooling and shares of service sector employment from the 1980s as instruments for these variables in the 1990s. As shown in Table 7, the results are qualitatively similar whether we use OLS or IV estimation for the EPL variable. However, the significance of the regulatory variables deteriorates somewhat in the regression that includes regulatory burdens on startups.

As another robustness check on equation (2), we also allow for the disturbances in the early 1990s and late 1990s to be correlated. To do this, we let $E\left(v_{i t} v_{i s}\right)=\rho \sigma^{2}$ for $t \neq s$ and all i. Here, $\rho$ denotes the correlation of the disturbances across the two periods, which is assumed to be the same across countries, and $\sigma^{2}$ denotes the variance of the disturbances.

Table 8 shows our GLS parameter estimates for the two baseline regressions, allowing for serial correlation. As shown there, it is generally the case that countries with IT expenditures higher than predicted by equation (2) in the early 1990s also tend to have higher IT expenditures in the late 1990s. Still, at least for the regression that includes the index of employment protection legislation, the regulatory variables are jointly significant at the 5 percent level.

As a final check on the regression explaining IT spending across countries, we examined whether the same factors are useful in determining the share of total investment in GDP. To this end, Table 9 contrasts our baseline specification for IT expenditures as a fraction of GDP with the case where investment as a share of GDP is the dependent variable. From this regression, we can see that the factors that appear to be important in accounting for IT spending are not as important for investment in general. This suggests that the decision to invest in information technologies is unique from other types of investment goods, as IT spending depends more sensitively on educational levels and is more restrained by restrictive regulatory practices than other types of investment.

\section{Theoretical Analysis}

We develop a vintage capital and labor model to evaluate the effects of a tax on firing workers on investment and productivity. Such a tax on firms delays the adoption of new technology, leading 
to a permanently lower level of aggregate productivity. As a result, the model is qualitatively consistent with our empirical findings that more burdensome employment protection legislation slows investment in information technologies and gains in productivity.

The model is similar to Cooper and Haltiwanger (1993) in that firms have a discrete decision each period on whether to scrap their old capital and install new capital embodying the latest technology. If a firm decides not to replace their current capital, they continue to operate with this vintage even though it is less productive than the latest vintage. On the other hand, if a firm opts to replace its capital, it gains access to the latest vintage but must pay a fixed cost to install the new capital. As a result of this cost, a firm may choose to delay replacing its capital even though it means they operate below the technological frontier.

The key friction we introduce into this environment is vintage labor. Just as firms decide to scrap old capital as it becomes obsolete and install new capital, firms also decide whether to improve the quality of its workforce. We model a firm's decision to upgrade the skills of their labor force by focusing on the complementary nature of technology and skills. Skills and the technology embedded in capital are perfect complements in the model, since a firm needs the latest vintage of workers to use the latest technology. We think of this assumption as capturing in a simple manner the skill-biased organizational change that often complements IT investment. $^{14}$

With technological change skill-biased in the model and some labor upskilling occuring through job turnover, a dismissal tax imposed on firms will delay their decision to upskill their labor force. And, since improved skills are required to operate the latest technology, a firm will also wait longer to install new capital. This in turn has negative implications for the level of aggregate output and productivity.

\footnotetext{
${ }^{14}$ For evidence on this point, see Bresnahan, Brynjolfsson, and Hitt (1999) and Autor, Levy, and Murname (2001) and references therein. These papers argue that IT capital acts as a substitute for low-skilled clerical work that can easily be routinized, while complementing the more complex cognitive tasks of managers and professionals.
} 


\subsection{Model}

The model is populated by two types of firms: final goods producers and intermediate goods producers. Final goods producers simply purchase the goods of the intermediate goods firms to make the economy's aggregate output. Intermediate goods producers combine labor and capital to produce their output, and they also make a dynamic decision about whether to update their vintages of labor and capital. In what follows, we emphasize a partial equilibrium version of the model by ignoring the decisions of households, and, as a result, wages and the aggregate price level in the model are simply exogenous.

\subsubsection{Final Goods Firms}

At time $t$, a final good, $Y_{t}$, is produced by a perfectly competitive firm. It does so by combining a continuum of intermediate goods, indexed by $i \in(0,1)$, using the technology:

$$
Y_{t}=\left[\int_{0}^{1} Y_{i t^{\frac{1}{\mu}}} d i\right]^{\mu}
$$

where $1 \leq \mu<\infty$ and $Y_{i t}$ denotes the time $t$ input of intermediate good $i$. Let $P_{i t}$ denote the time $t$ price of intermediate good $i$ in terms of the final good. Profit maximization implies:

$$
Y_{i t}=\left(P_{i t}\right)^{\frac{\mu}{1-\mu}} Y_{t}
$$

According to (4), the demand for intermediate good $i$ is a decreasing function of the relative price of that good, and an increasing function of aggregate output, $Y_{t}$.

\subsubsection{Intermediate Goods Firms}

At date $t$, each intermediate goods producer is a monopolist who combines a unit of a capital with labor to produce output, $Y_{i t}(\tau)$, according to

$$
Y_{i t}=A \theta_{i t}^{\alpha} n_{i t}^{1-\alpha}
$$

with $0<\alpha<1$. Here, $\theta_{i t}$ indexes the vintage of technology embodied in a monopolist's capital at the beginning of period $\mathrm{t}$ and $n_{i t}$ denotes the number of laborers hired by the monopolist 
in period $t$. At every date, the monopolist decides whether to scrap his capital and replace it with one unit of capital of a more recent vintage. Let $d_{i t} \in\{0,1\}$ index a monopolist's choice of whether he updates his unit of capital or not, so that $d_{i t}=1$ indicates that the monopolist chooses to update his capital at date $t$. If a monopolist does update his vintage of capital, then the most advanced state of technology, $\theta_{A t+1}$ becomes available to him for production next period. We assume that the most advanced technology, $\theta_{A t}$, evolves exogenously according to

$$
\theta_{A t}=\eta \theta_{A t-1}
$$

with $\eta>1$. If a monopolist chooses not to update his capital, then next period he still has vintage $\theta_{i t}$ available to him. A producer's vintage of capital available for production at the beginning of period $t+1$ will be

$$
\theta_{i t+1}=\left\{\begin{array}{cc}
\theta_{A t+1} & \text { if } d_{i t}=1 \\
\theta_{i t} & \text { if } d_{i t}=0
\end{array} .\right.
$$

Intermediate goods firms also hire workers to produce output. Laborers differ in their abilities to use different technologies so that at date $t$,

$$
n_{i t} \in\left\{n_{i t}\left(\theta_{i 0}\right), n_{i t}\left(\theta_{A 0}\right), n_{i t}\left(\theta_{A 1}\right), \ldots, n_{i t}\left(\theta_{A t}\right)\right\}
$$

with vintage $\theta_{i 0} \leq \theta_{A 0}$ and $\theta_{i 0}$ given. We assume that workers of type, $\theta_{A \tau}$, can use technologies, $\theta_{A \tau+j}$ where $j \leq 0$ but not $j>0$. Given this assumption, at date $t$ firm $i$ will hire workers of ability of at least $\theta_{i t}$. Also, given our assumption below that wages are an increasing function of a worker's skill type, a firm will only hire workers whose skill level corresponds to their vintage of technology so that

$$
n_{i t}=n_{i t}\left(\theta_{i t}\right)
$$

In hiring workers, intermediate goods firms take wages as given. Since our focus is primarily on the adoption of new technology by firms in the presence of a tax on firing workers, we do not model the household labor decision and instead assume that for a given vintage of laborers that wages are constant over time. ${ }^{15}$ This assumption implies that

$$
W_{t}\left(\theta_{A \tau}\right)=W\left(\theta_{A \tau}\right) \quad \forall t, \tau
$$


For a given firm, however, the wage it pays will evolve over time as it updates its capital and hires workers from different vintages. Hence, firm $i$ with vintage $\theta_{i t}$ workers at date t will pay wage $W\left(\theta_{i t+1}\right)$ next period where

$$
W\left(\theta_{i t+1}\right)=\left\{\begin{array}{cc}
W\left(\theta_{A t+1}\right) & \text { if } d_{i t}=1 \\
W\left(\theta_{i t}\right) & \text { if } d_{i t}=0
\end{array} .\right.
$$

Besides their wage cost, firms also must pay a tax if they choose to layoff workers. We model this dismissal tax, $\Psi_{i t}$, as follows:

$$
\Psi_{i t}=\left\{\begin{array}{ccc}
-\phi W\left(\theta_{i t-1}\right) \Delta n_{i t}\left(\theta_{i t-1}\right) & \text { if } & \Delta n_{i t}\left(\theta_{i t-1}\right)<0 \\
0 & \text { otherwise }
\end{array}\right.
$$

where $\Delta n_{i t}\left(\theta_{i t-1}\right)=n_{i t}\left(\theta_{i t-1}\right)-n_{i t-1}\left(\theta_{i t-1}\right)$. According to (12), if a firm chooses to hire all of its workers back at date $t$ from date $t-1$, it avoids paying the dismissal tax. However, if a firm hires less of the vintage $\theta_{i t-1}$ workers back at date $t$, it gets hit with a tax that is equal to a percentage, $\phi$, of the wage bill of the workers it does not rehire.

In the case where a firm decides to upgrade its capital at date $t$, it will also need workers of vintage $\theta_{A t+1}$. In principle, this could involve laying off the $n_{i t}\left(\theta_{i t}\right)$ workers at date $t+1$. However, we allow a firm to train $\psi n_{i t}\left(\theta_{i t}\right)$ workers into vintage $\theta_{A t+1}$ workers. We assume that $0 \leq \psi<1$, reflecting the fact that not all of a firm's current workers can be trained to use the latest technology. With the ability to train some of its date $t$ workers, a firm's firing cost at date $t+1$ will be

$$
\Psi_{i t+1}=\phi(1-\psi) W\left(\theta_{i t}\right) n_{i t}\left(\theta_{i t}\right)
$$

when it chooses to upgrade its technology at date $t$.

Given its labor costs and the dismissal tax, profits of firm $i$ at date $t$ are given by:

$$
\pi_{i t}=P_{i t} Y_{i t}-W\left(\theta_{i t}\right) n_{i t}\left(\theta_{i t}\right)-\Psi_{i t}-F_{i t} d_{i t},
$$

\footnotetext{
${ }^{15} \mathrm{~A}$ drawback to leaving wages exogenous in this manner is that we are unable to examine the effect on wages of labor supply decisions by households and labor demand decisions by other firms and in turn on an individual firm's decision to adopt new technology. For example, as more firm's decide to update their vintage of capital, this pushes up the wages for high-skilled workers and potentially causes an individual firm to delay its adoption decision. However, even if such general equilibrium effects are present in our environment, a higher firing tax will still delay the adoption of new technology.
} 
where $F_{i t}$ is a fixed cost that firms incur when they switch technologies. An intermediate goods producer's problem can be defined recursively. To do this, we define the state vector for firm $i$ at the beginning of date $t$ and date $t+1$ to be

$$
z_{i t}=\left(\theta_{i t}, n_{i t-1}\left(\theta_{i t-1}\right)\right), \quad z_{i t+1}=\left(\theta_{i t+1}, n_{i t}\left(\theta_{i t}\right)\right) .
$$

Let $V\left(z_{i t}\right)$ denote the value function of firm $i$, then an intermediate goods producer's problem can be represented by the functional equation:

$$
V\left(z_{i t}\right)=\max _{d_{i t}, n_{i t}, Y_{i t}, P_{i t}}\left[\pi_{i t}+\beta V\left(z_{i t+1}\right)\right]
$$

which is maximized subject to (4)-(7), (9), (11)-(14).

\subsubsection{Recursive Equilibrium}

We make two other assumptions regarding intermediate goods firms. First, we assume that wages and the fixed cost of installing the new capital grow in proportion to the growth rate of the most advanced technology so that:

$$
w=\frac{W\left(\theta_{A t}\right)}{\theta_{A t}^{\alpha}}, F_{i}=\frac{F_{i t}}{\theta_{A t}^{\alpha}} .
$$

We also allow the initial technology $\theta_{i 0}$ to differ across intermediate goods producers. Specifi-

cally, $\theta_{i 0}$ can take on $\mathrm{N}$ different values so that $\theta_{i 0} \in\left\{\theta_{A 0}, \frac{\theta_{A 0}}{\eta}, \ldots, \frac{\theta_{A 0}}{\eta^{N-1}}\right\}$, and producer i where $i \in\left[0, \frac{1}{N}\right]$ has technology $\theta_{A 0}$, producer $\mathrm{j}$ where $j \in\left[\frac{1}{N}, \frac{2}{N}\right]$ has $\frac{\theta_{A 0}}{\eta}$, and so on. In this case, there will be $\mathrm{N}$ different cohorts of producers, and since a producer has the same problem as other producers in his cohort, we focus on computing a symmetric equilibrium where each producer in a given cohort makes the same decisions. As a result, $V\left(z_{i t}\right)=V\left(z_{j t}\right)$ for $i, j \in\left[\frac{l}{N}, \frac{l+1}{N}\right]$ and it follows that the functional, $V(\cdot)$, is the same for all producers since they only differ by their initial level of technology. A recursive equilibrium is then defined as:

- a value function $V\left(z_{i t}\right)$, decision rules $g^{d}\left(z_{i t}\right), g^{n}\left(z_{i t}\right)$, and $g^{y}\left(z_{i t}\right)$ for $d_{i t}, n_{i t}\left(\theta_{i t}\right)$, and $Y_{i t}$ and a pricing function, $P_{i t}=g^{p}\left(z_{i t}\right)$ such that $V\left(z_{i t}\right)$ satisfies (4)-(15) for $i \in(0,1)$ given $Y_{t}$. 
- $g^{p}\left(z_{i t}\right)$ is an optimal pricing function and $g^{d}\left(z_{i t}\right), g^{n}\left(z_{i t}\right)$, and $g^{y}\left(z_{i t}\right)$ are optimal decision rules for (4)-(15) for $i \in(0,1)$ given $Y_{t}$.

- Intermediate goods quantities and prices satisfy:

$$
\begin{aligned}
& Y_{t}=\left(\sum_{j=1}^{N} \frac{1}{N} g^{y}\left(z_{j t}\right)^{1 / \mu}\right)^{\mu}, \\
& 1=\left[\sum_{j=1}^{N} \frac{1}{N} g^{p}\left(z_{j t}\right)^{\frac{1}{1-\mu}}\right]^{(1-\mu)},
\end{aligned}
$$

where equation (17) follows from integrating (4) and imposing (3).

\subsection{Numerical Simulations}

Obtaining analytical solutions to the dynamic programming is not possible, since we can not obtain closed form solutions for the decision rules of an individual producer. This is due to the nondifferentability introduced by the dismissal cost as well as having to deal with the heterogeneity across producers. Instead, we rescale the problem into a stationary one and use value function iterations. ${ }^{16}$ This rescaling involves dividing $\theta_{i t}$ by $\theta_{A t}$ and noting that this rescaled variable resides on the set, $\left[1, \frac{1}{\eta}, \frac{1}{\eta^{2}}, \ldots\right]$. With the exceptions of output prices, $d_{i}$, and employment, the other variables are rescaled by dividing by $\theta_{A t}^{\alpha}$. We also discretize a firm's employment decision and constrain the values of $n_{i t}\left(\theta_{i t}\right)$ to be the set of positive integers.

This allows us to describe the model's steady state growth path. As in Cooper and Haltiwanger (1993) and Cooper, Haltiwanger, and Power (2001), the model displays deterministic cycles where the vintage of capital remains unchanged for a number of periods and then is eventually upgraded. As we show below, a higher dismissal tax results in a longer cycle or number of periods before capital is scrapped and replaced with a newer vintage.

To illustrate this point, we construct a numerical example to examine the replacement cycle for two economies that differ only in the dismissal tax paid by firms. In the first economy,

\footnotetext{
${ }^{16}$ We used MATLAB 6.1 to perform these value function iterations. The code is available upon request.
} 
the dismissal tax is set to 0 and in the second, the dismissal tax is set to 5 percent of the wage bill so that $\phi=0.05$. For the rest of the parameters, we set $\beta=0.99, \eta=(1.025)^{0.25}, \alpha=$ $0.36, \mu=1.05, w=1, \psi=0.5$, and $F_{i}=F=0$ for all i. Also the parameter, $A$, was set so that a firm without firing costs chooses to hire ten employees. Although the parameters are chosen to be consistent with a quarterly frequency, the primary purpose of the model is not to evaluate its quantitative performance. Rather, our focus here is on exploring the qualitative implications of the effect of firing costs on investment and productivity.

In the example, there are also six different cohorts of firms, each with a different initial level of technology. Let $\mathrm{j}$ index these cohorts then the initial level of technology for a cohort is given by

$$
\theta_{j 0}=\left(\frac{1}{\eta^{j-1}}\right) \theta_{A 0},
$$

where $j=1,2, . ., 6$ and $\theta_{A 0}=1$. As we discuss below, in the case where $\phi=0.05$, this difference in initial technologies will cause firms to stagger their investment decisions so that at each date only a sixth of the firms update their vintage of capital.

For the economy with $\phi=0$, it is possible to show that intermediate goods producers, regardless of their initial technology, will invest every period in new vintages of capital and labor. This follows from the fact that $F=0$ so that there is no cost associated with installing new capital. In addition, with $\phi=0$, we can use the first order conditions from the producer's problem to show that in equilibrium,

$$
n_{j}=\left[\frac{A(1-\alpha)}{\mu w}\right]^{\frac{1}{\alpha}},
$$

for $j \in[1,2, . ., 6]$. From this expression, it is clear that a firm's demand for labor is a decreasing function of the real wage.

Figure 7 shows the steady state growth path for the two economies. As shown in the panel in the upper left corner, a firm in the economy with $\phi=0.05$ upgrades its capital only every six periods compared to every period in the economy without a tax on firing workers. Intuitively, the dismissal tax raises the cost to installing new capital, since firms must simultaneously upskill part of their workforce by replacing old workers with more skilled workers. However, a firm 
will eventually choose to upgrade their capital, as their present vintage becomes technologically more obsolete over time and the gains to upgrading to the latest vintage become overwhelming.

Since firms only invest in new technology every six periods, only a sixth of the firms are at the technological frontier at a given date. In contrast, in the economy with $\phi=0$, all firms invest in the new technology every period. As shown by the dashed line in the upper right panel of Figure 7, this leads to an initial burst in technological progress as all firms invest, and the firms with a low level of technology catch up to the leading firms. After that date, technology grows by $\eta$ each period.

In comparison, with only one cohort investing in a given period in the economy with a firing tax, there is no initial burst of technological progress at date 0 . Rather, as shown by the solid line in the upper right panel, technological progress increases by $\eta$ in the initial period and thereafter. The firing tax causes slower initial growth and a permanent difference in technology between the two economies, reflecting the older vintage of capital in the economy with $\phi=0.05$.

With older vintages of capital and labor in the economy with $\phi=0.05$, productivity defined as $\frac{Y}{n}$ where $n=N^{-1} \sum_{j=1}^{N} n_{j}$, is also permanently lower in the economy with a higher firing tax. Initially, as shown in the bottom left panel of Figure 7, the economy without a firing tax experiences faster productivity growth but thereafter the two economies have the same rates of productivity growth. Wages also display a similar pattern, as the economy without a firing tax has more skilled laborers on average that receive greater compensation.

\section{Conclusions}

Overall, our results support the view that technological adoption and productivity growth are generally impaired in countries with restrictive regulatory environments. Although such regulatory practices may insulate workers from the process of job creation and job destruction (and existing firms from the entry of startups), they also appear to have slowed the rate of adoption of information technologies in some countries. This in turn has played a role in explaining differences in productivity growth across countries in the 1990s. 
An important remaining question is how long these differences in productivity growth will be sustained. Although regulations may impede the diffusion of technology, productivity growth does not necessarily have to remain persistently higher in the United States than in other countries. In our model, countries with a more burdensome tax on firing workers eventually adopt these new technologies and in the end experience the same rate of productivity growth. However, the model also implies that these countries will also have fewer skilled laborers and an older stock of capital on average than countries with a less burdensome tax on firing workers, leading to lower levels of productivity. Thus, the model suggests that in some countries labor market reform may be necessary to reduce differences in productivity levels vis-à-vis the United States. 


\section{Data Appendix}

The list of variables, a brief definition, and our data sources are listed below. In the case of the IT production and the stock market capitalization variables, we had some missing values and we also describe how those were treated.

- Labor Productivity Growth: Growth in business sector real GDP less growth in hours worked. Sources: Real GDP and employment data are from OECD (2001b) and hours per worker series from Scarpetti, Bassinini, Pilat, and Schreyer (2001) and from national sources in some years.

- IT Expenditures: Nominal expenditures on computers, related hardware, and software by households, firms, and the government sector as a percentage of nominal GDP. For the productivity regressions, we excluded spending on IT services but included this category for the regressions based on equation (2). Source: WITSA (2000).

- IT Production: Nominal spending on office and computing equipment, and radio, television, and communication equipment as a percentage of nominal GDP. Source: OECD (2001c). For this variable, we had missing values for Australia from 1994-96. We linearly interpolated those missing values. For the Netherlands, only a broader measure, machinery and equipment production, was available. We rescaled this broader measure down using data on the IT sector in the Netherlands in 1997 from OECD (2001d).

- Investment Expenditures: For the regressions based on equation 1, we used real investment in the business sector as a share of real business sector GDP. Source: OECD (2001b). For the IT regressions of equation 2, we used nominal investment expenditures as a share of nominal GDP. Source: Haver Analytics (2001).

- Employment-Population Ratio: Ratio of employment (persons) to population, 15 and older. Source: OECD (2001b).

- Government Expenditures: Nominal government expenditures as a share of nominal GDP. Source: OECD (2001b). 
- Trade Openness Index: Index constructed from data on tariff rates, black-market premiums, restrictions on capital movements, and gap between actual and expected trade. Source: Gwartney, Lawson, and Samida (2001).

- R\&D expenditures: Nominal domestic expenditures on research and experimental development by the business enterprise sector as a percentage of GDP. Source: OECD (2001a).

- Output Gap: Percentage difference between actual and potential GDP as measured by the OECD. Source: OECD (2001b).

- Per-capita GDP: Real GDP in 1995 prices and exchange rates divided by population aged 15 and older. Source: OECD (2001b).

- Employment Protection Legislation: Index constructed from examining legislation on severance pay, procedures for dismissal, and rules involving the use of temporary workers. Source: Nicoletti, Scarpetta, and Boylaud (1999).

- Regulatory Burdens on Startups: Index constructed from surveys of business managers on the extent to which administrative procedures are a hindrance to starting a new business. Sources: World Competitiveness Report 1993 and Global Competitiveness Report 1998.

- Regulatory Burdens: Index constructed from surveys of business managers on the pervasiveness of business regulations. Sources: World Competitiveness Report 1993 and Global Competitiveness Report 1998.

- Years of Schooling: Average number of years in education in the working-age population, 1990 and 1998. Source: Bassassini, Scarpetta, and Hemmings (2001).

- Service Employment: Employment in service sector as a percentage of total employment. Source: OECD (2001c).

- Stock Market Capitalization: Market capitalization as a percent of GDP, 1990 and 1999. For Ireland, we had a missing value for 1999 and dropped Ireland from equation (2) when this variable was used as a control. Source: World Bank (2001). 
- Real Interest Rate: Average real (ex post) money market rate, 1992 and 1999. Source: Haver Analytics (2001).

- Availability of Venture Capital: Index constructed from surveys of business managers on availability of venture capital for business development. Sources: World Competitiveness Report 1993 and Global Competitiveness Report 1998. 


\section{References}

[1] Arellano, M., 1987, "Computing Robust Standard Errors for Within-groups Estimators," Oxford Bulletin of Economics and Statistics, 49, 431-434.

[2] Autor, D., Levy, F., and R.J. Murname, 2001, "The Skill Content of Recent Technological Change: An Empirical Exploration," NBER Working Paper No. 8337 (Cambridge: National Bureau of Economic Research).

[3] Beaudry, P. and F. Collard, 2001, "Why Has the Employment-Productivity Tradeoff Among Industrialized Countries Been So Strong?" (unpublished: Vancouver: University of British Columbia).

[4] Bresnahan, T.F., Brynjolfsson, E., Hitt, L.M., 1999, "Information Technology, Workplace Organization, and the Demand for Skilled Labor: Firm-Level Evidence," NBER Working Paper No. 7136 (Cambridge: National Bureau of Economic Research).

[5] Cardarelli, R., 2001, "Is Australia a 'New Economy'?" in Australia: Selected Issues and Statistical Appendix, IMF Country Report No. 01/55 (Washington: International Monetary Fund).

[6] Caselli, F. and W. J. Coleman, 2001, "Cross-Country Technology Diffusion: The Case of Computers," NBER Working Paper No. 8130 (Cambridge: National Bureau of Economic Research).

[7] Colecchia, A. and P. Schreyer, 2001, "ICT Investment and Economic Growth in the 1990s: Is the United States a Unique Case? A Comparative Study of Nine OECD Countries," OECD Directorate for Science, Technology, and Industry Working Paper No. 7 (Paris: Organization for Economic Cooperation and Development).

[8] Cooper, R. and J. Haltiwanger, 1993, "The Aggregate Implications of Machine Replacement: Theory and Evidence," American Economic Review, 83, pp. 360-82. 
[9] Cooper, R., J. Haltiwanger, and L. Power, 1999, "Machine Replacement and the Business Cycle: Lumps and Bumps," American Economic Review, 89, pp. 921-46.

[10] Daveri, F., 2001, "Information Technology and Growth in Europe," (unpublished: Parma: University of Parma).

[11] Doornik, J. and D. F. Hendry, 2001, Econometric Modeling Using PcGive, Vol. III, (London: Timberlake Consultants Ltd).

[12] Feldstein, M., 2001, "Comments \& Analysis," in The Financial Times, June 28.

[13] Greenspan, A., 2000, "Technology and the Economy," speech before the Economic Club of New York, January 13. Available on the Internet at www.federalreserve.gov/boarddocs/speeches/2000.

[14] Gordon, R.J., 2000, "Does the 'New Economy' Measure Up to the Great Inventions of the Past?" Journal of Economic Perspectives, Vol. 14 (Fall), pp. 49-74.

[15] Gust C. and J. Marquez, 2000, "Productivity Developments Abroad," Federal Reserve Bulletin, 86, pp. 665-81.

[16] Gwartney, J., Lawson, R., and D. Samida, 2001, Economic Freedom of the World: 2001 Annual Report, (Vancouver: Fraser Institute).

[17] Haver Analytics, 2001, Haver International Database.

[18] IMD and World Economic Forum, 1993, World Competitiveness Report 1993.

[19] International Monetary Fund, 2001, "The Information Technology Revolution," in The World Economic Outlook, October, (Washington: International Monetary Fund).

[20] Jorgenson, D.W. and K.J. Stiroh, 2000, "Raising the Speed Limit: U.S. Economic Growth in the Information Age," Brookings Papers on Economic Activity: 1, Brookings Institution, pp. 161-67. 
[21] Pilat, D. and F. Lee, 2001, "Productivity Growth in ICT-Producing and ICT-Using Industries-A Source of Growth Differentials in the OECD?" OECD Directorate for Science, Technology, and Industry Working Paper No. 4 (Paris: Organization for Economic Cooperation and Development).

[22] Nicoletti, G., S. Scarpetta, and O. Boylaud, 1999, "Summary Indicators of Product Market Regulation with an Extension to Employment Protection Legislation," OECD Economic Department Working Papers (Paris: Organization for Economic Cooperation and Development).

[23] Oliner, S.D. and D.E. Sichel, 2000, "The Resurgence of Growth in the Late 1990s: Is Information Technology the Story?," Journal of Economic Perspectives, Vol. 14 (Fall), pp. $3-22$.

[24] Organization for Economic Cooperation and Development, 2001a, Main Science and Technology Indicators 2001-1, May, (Paris: Organization for Economic Cooperation and Development).

[25] Organization for Economic Cooperation and Development, 2001b, OECD Economic Outlook No. 69, June, (Paris: Organization for Economic Cooperation and Development).

[26] Organization for Economic Cooperation and Development, 2001c, STAN Database, (Paris: Organization for Economic Cooperation and Development).

[27] Organization for Economic Cooperation and Development, 2001d, Measuring the ICT Sector, (Paris: Organization for Economic Cooperation and Development).

[28] Oulton, Nicholas, 2001, "ICT and Productivity Growth in the United Kingdom," Bank of England Working Paper No. 140, July, (London: Bank of England).

[29] Roeger, W., 2001, "The Contribution of Information and Communication Technologies to Growth in Europe and the United States: A Macroeconomic Analysis," Economic Papers, No. 147, European Commission. 
[30] Scarpetta S., A. Bassanini, D. Pilat, and P. Schreyer, 2000, "Economic Growth in the OECD Area: Recent Trends at the Aggregate and Sectoral Levels," OECD Economic Department Working Papers (Paris: Organization for Economic Cooperation and Development).

[31] Scarpeta, S., A. Bassanini, and P. Hemmings, 2001, "Economic Growth: The Role of Policies and Institutions: Panel Data Evidence from OECD Countries," OECD Economic Department Working Papers No. 283 (Paris: Organization for Economic Cooperation and Development).

[32] Schreyer, P., 2000, "The Contribution of Information and Communication Technology to Output Growth: A Study of the G7 Countries," OECD Directorate for Science, Technology, and Innovation Working Paper No. 2000/2. (Paris: Organization for Economic Cooperation and Development).

[33] Stiroh, K., 2001, "Information Technology and the U.S. Productivity Revival: What Do the Industry Data Say?" Staff Report No. 115 (New York: Federal Reserve Bank of New York).

[34] U.S. Council of Economic Advisors, 2001, Economic Report of the President (Washington: U.S. Government Printing Office).

[35] U.S. Department of Labor, Bureau of Labor Statistics, 2000, International Comparisons of Manufacturing Productivity and Unit Labor Cost Trends, (Washington DC: Bureau of Labor Statistics).

[36] Van Ark, B., 2001, "The Renewal of the Old Economy: Europe in an Internationally Comparative Perspective," OECD Directorate for Science, Technology, and Industry Working Paper No. 5 (Paris: Organization for Economic Cooperation and Development).

[37] White, H., 1980 "A Heteroscedasticity-Consistent Covariance Matrix Estimator and a Direct Test for Heteroscedasticity," Econometrica, 48, pp. 817-838. 
[38] World Bank, 2001, World Development Indicators.

[39] World Economic Forum, 1998, Global Competitiveness Report 1998.

[40] World Information Technology Service Alliance (WITSA), 2000, Digital Planet 2000: The Global Information Economy. 
Figure 1

IT Expenditures and Labor Productivity Growth

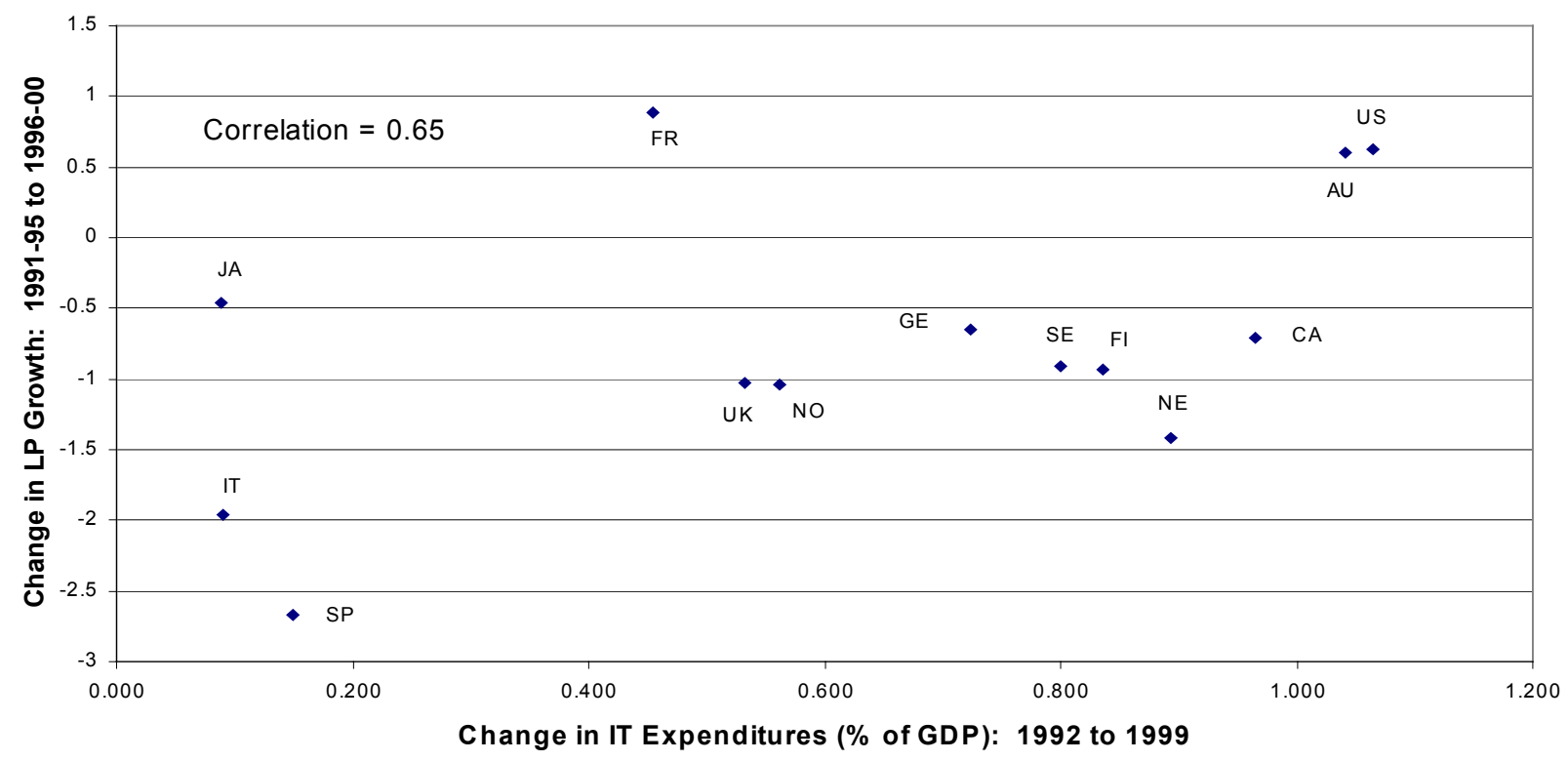

Figure 2

IT Expenditures and Employment Protection Legislation

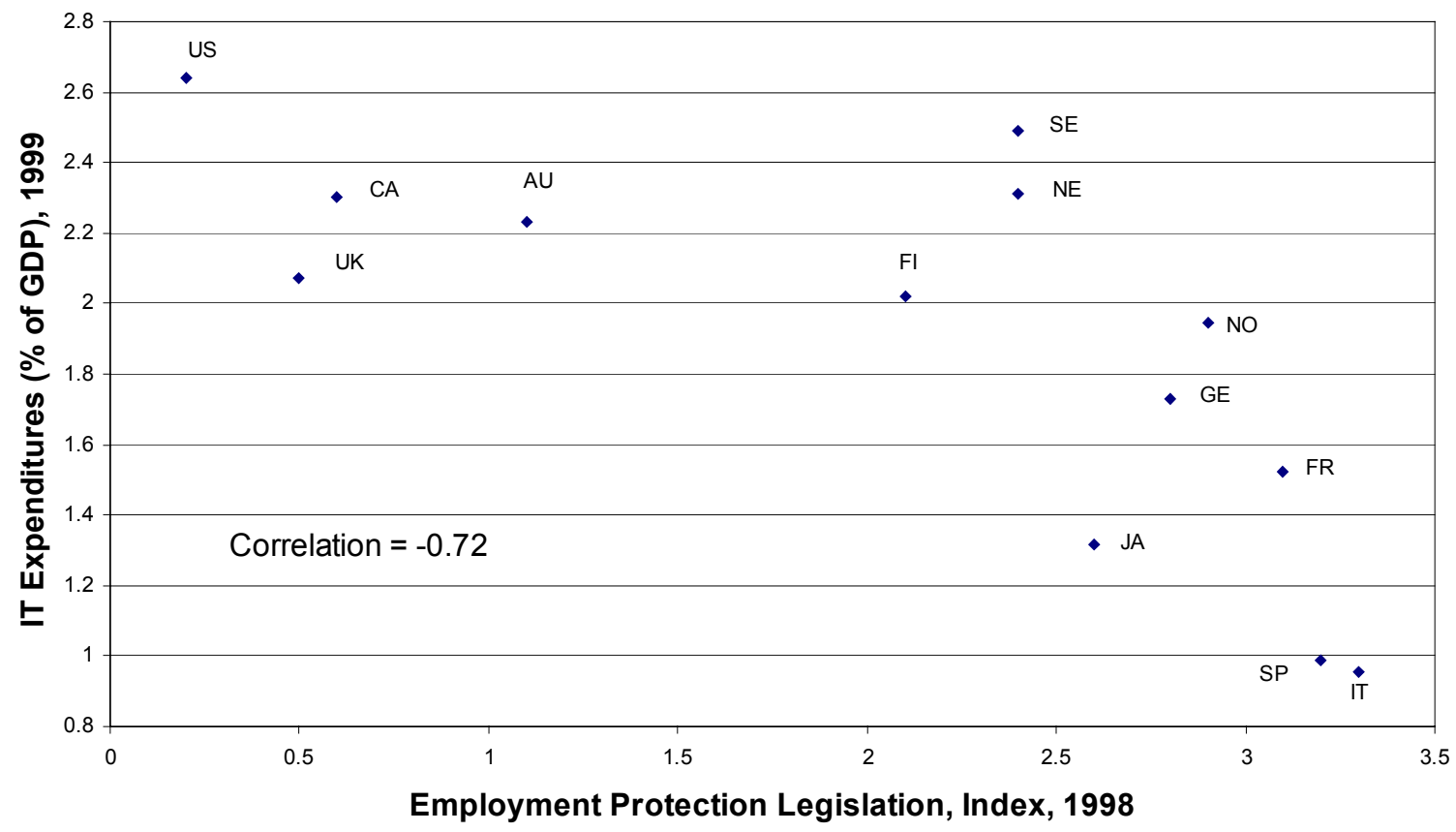


Table 1

Labor Productivity Growth of Business Sector

(Percent, Average Annual Rate)

\begin{tabular}{|c|c|c|c|}
\hline & $\begin{array}{c}1981- \\
1995\end{array}$ & $\begin{array}{l}1996- \\
2000\end{array}$ & Acceleration \\
\hline & (1) & (2) & $(3)=(2)-(1)$ \\
\hline United States & 1.3 & 2.5 & 1.2 \\
\hline Canada & 1.5 & 1.1 & -0.4 \\
\hline France & 2.9 & 2.6 & -0.3 \\
\hline Germany $^{a}$ & 2.4 & 1.8 & -0.6 \\
\hline Italy & 2.4 & 1.3 & -1.1 \\
\hline Japan & 3.0 & 1.6 & -1.5 \\
\hline United Kingdom & 2.1 & 1.5 & -0.6 \\
\hline Australia & 1.6 & 2.8 & 1.2 \\
\hline Finland & 3.8 & 3.9 & 0.1 \\
\hline Netherlands ${ }^{\mathrm{b}}$ & 2.3 & 1.3 & -1.0 \\
\hline Norway & 2.1 & 1.7 & -0.4 \\
\hline Spain & 3.4 & 0.7 & -2.7 \\
\hline Sweden & 1.9 & 2.1 & 0.2 \\
\hline
\end{tabular}


Figure 3

Labor Productivity Growth: Actual and Moving Average
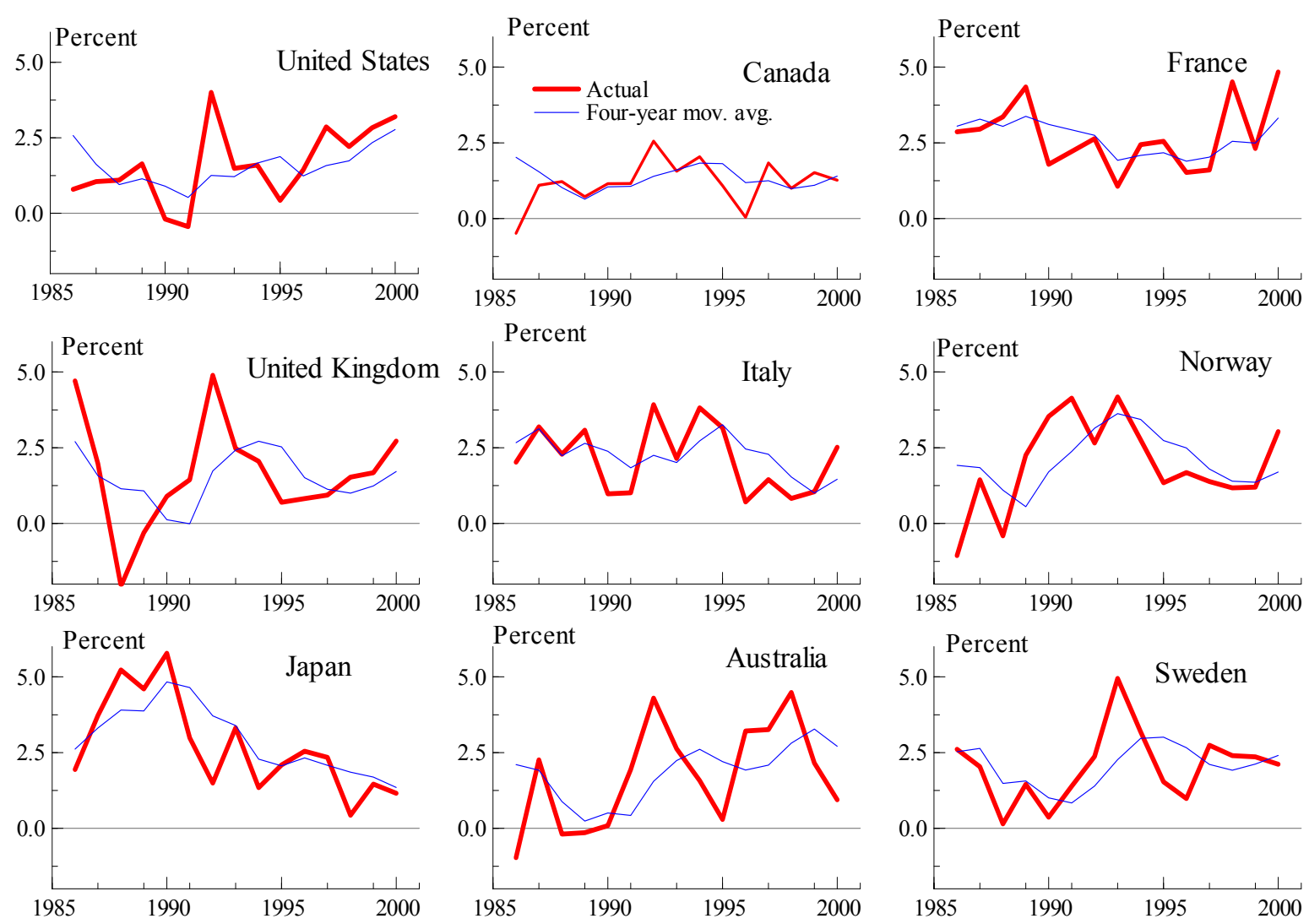
Figure 4

\section{IT Production}

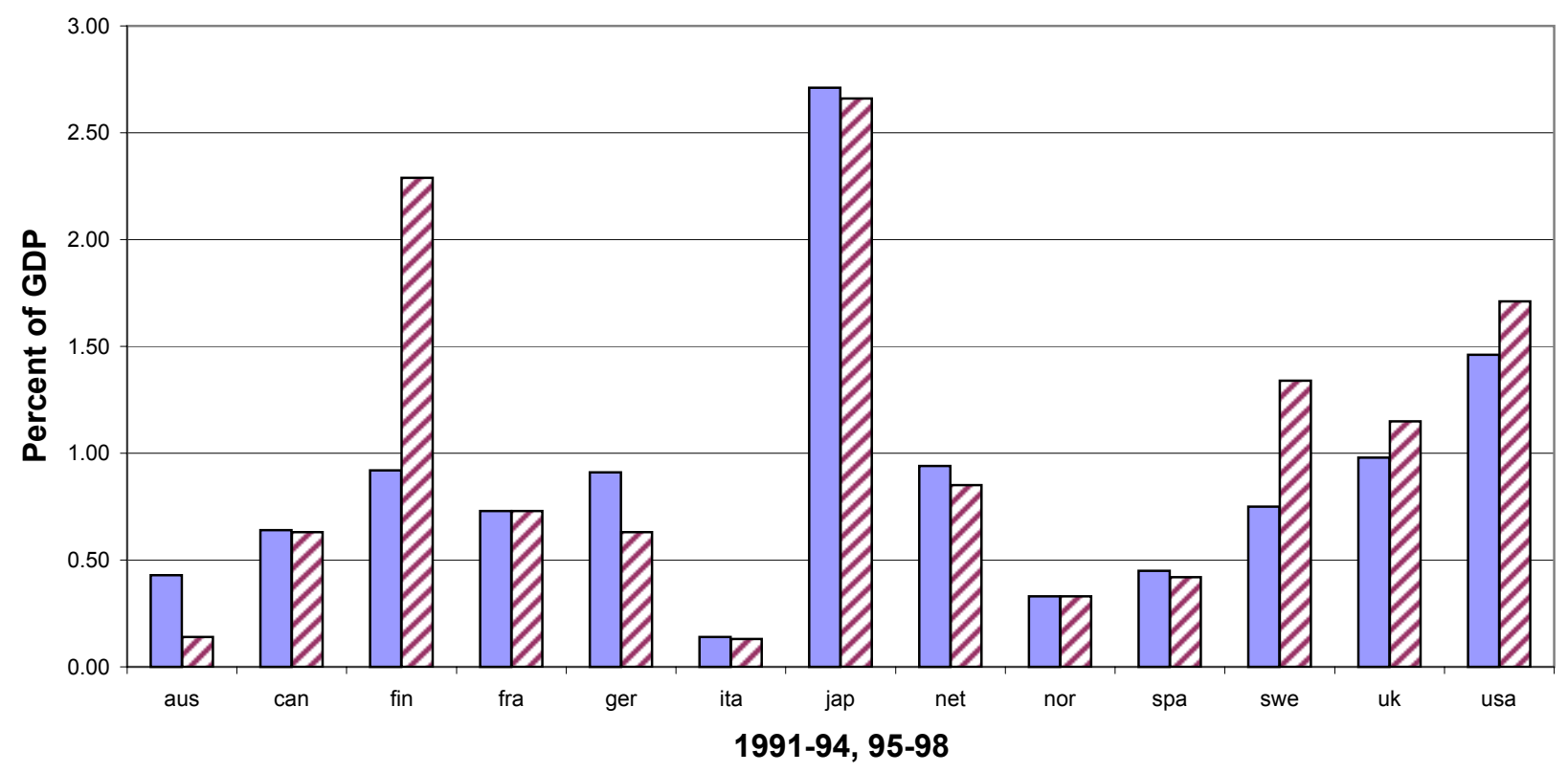

Figure 5

IT Hardware and Software Expenditures

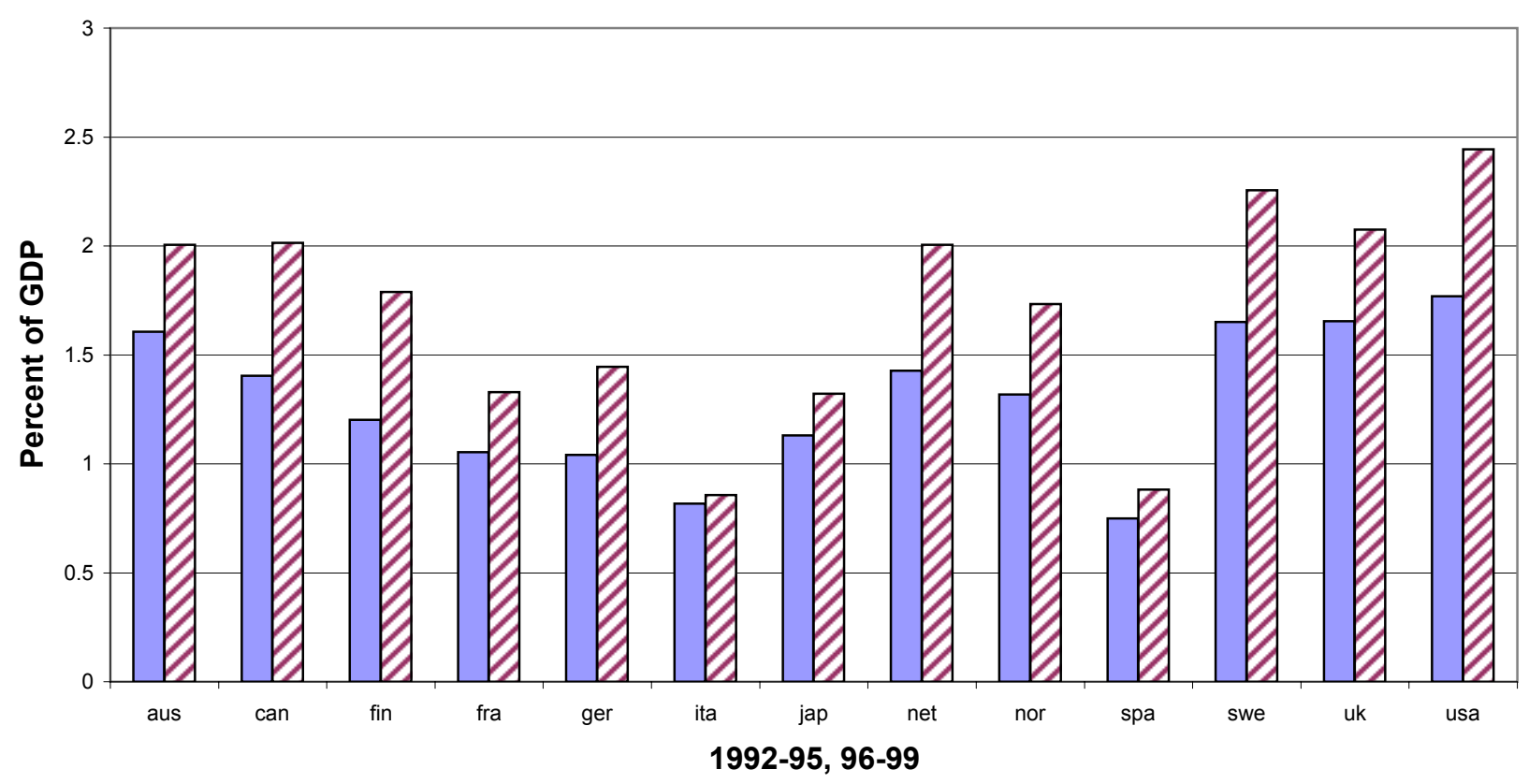


Table $2^{1}$

Parameter Estimates for Labor Productivity Growth Equation -- Country-Fixed Effects

\begin{tabular}{|c|c|c|c|c|c|c|}
\hline Lagged Regressors $^{2}$ & M1 & M2 & M3 & M4 & M5 & M6 \\
\hline \multirow[t]{2}{*}{ IT Production / GDP } & 1.071 & 1.058 & 1.411 & 1.082 & 0.934 & 1.071 \\
\hline & 0.374 & 0.341 & 0.512 & 0.414 & 0.346 & 0.377 \\
\hline \multirow[t]{2}{*}{ IT Expenditures / GDP } & 1.150 & 1.119 & 1.226 & 0.896 & 0.928 & 1.150 \\
\hline & 0.422 & 0.649 & 0.426 & 0.683 & 0.595 & 0.698 \\
\hline \multirow[t]{2}{*}{$\Delta$ (Employment / Pop $)$} & -0.786 & -0.791 & -0.769 & -0.788 & -0.810 & -0.786 \\
\hline & 0.112 & 0.127 & 0.123 & 0.109 & 0.118 & 0.134 \\
\hline \multirow[t]{2}{*}{ Government / GDP } & & -0.006 & & & & \\
\hline & & 0.064 & & & & \\
\hline \multirow[t]{2}{*}{ R\&D Spending / GDP } & & & -1.179 & & & \\
\hline & & & 1.243 & & & \\
\hline \multirow[t]{2}{*}{ Investment / GDP } & & & & 0.066 & & \\
\hline & & & & 0.108 & & \\
\hline \multirow[t]{2}{*}{ Output Gap } & & & & & 0.085 & \\
\hline & & & & & 0.119 & \\
\hline \multirow[t]{2}{*}{ Per-Capita GDP (1983-90) } & & & & & & 0.000 \\
\hline & & & & & & 0.154 \\
\hline \multicolumn{7}{|l|}{ Joint significance } \\
\hline Of IT variables ${ }^{3}$ & 0.000 & 0.002 & 0.002 & 0.002 & 0.001 & 0.001 \\
\hline $\operatorname{SER}(\%)$ & 1.06 & 1.07 & 1.06 & 1.06 & 1.06 & 1.06 \\
\hline Adjusted R-squared & 0.44 & 0.43 & 0.43 & 0.43 & 0.43 & 0.43 \\
\hline \# Parameters & 16 & 17 & 17 & 17 & 17 & 17 \\
\hline Residual Independence ${ }^{4}$ & 0.80 & 0.80 & 0.82 & 0.64 & 0.80 & 0.80 \\
\hline
\end{tabular}

${ }^{1}$ For the dependent variable, the sample mean is $2.14 \%$ and the sample standard deviation is $1.41 \%$.

${ }^{2}$ For each variable, top entry is point estimate and bottom entry is the Arellano (1987) heteroskedasticity-corrected standard error.

${ }^{3}$ Significance level needed to reject the null hypothesis that IT variables are jointly zero using a Wald test.

${ }^{4}$ Significance level needed to reject the null hypothesis that there is no correlation across periods and countries. See Doornik and Hendry (2001, page 94) for details. 
Figure 6

\section{Employment Protection Legislation, Index}

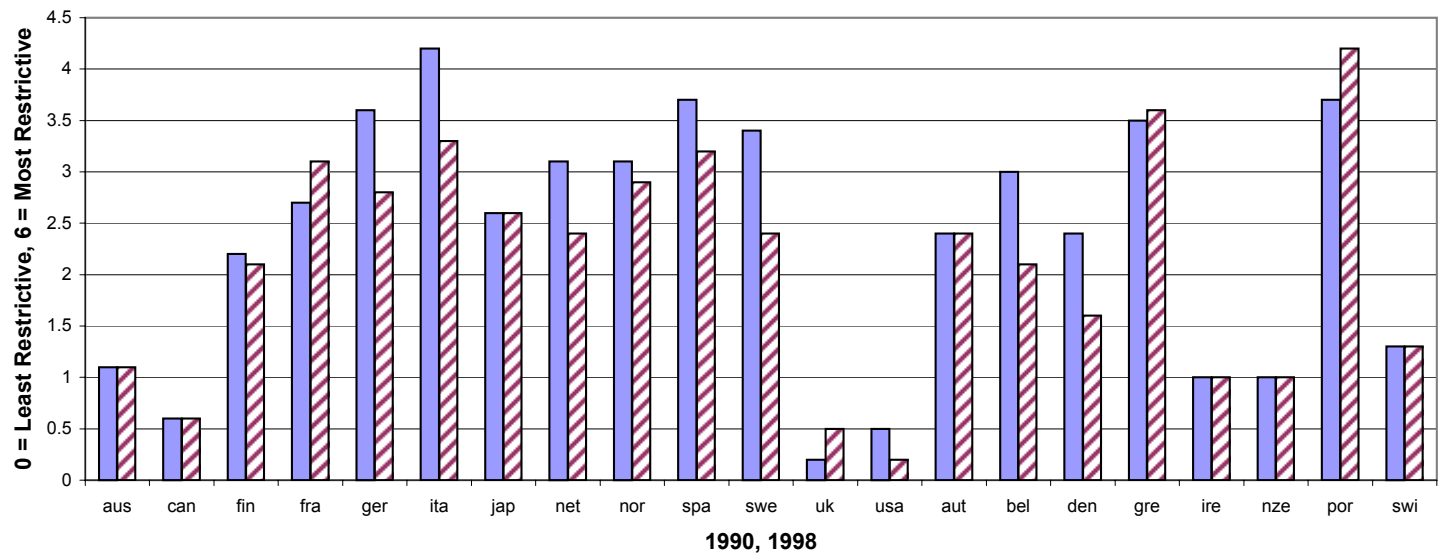

Regulatory Burdens on Startups, Index

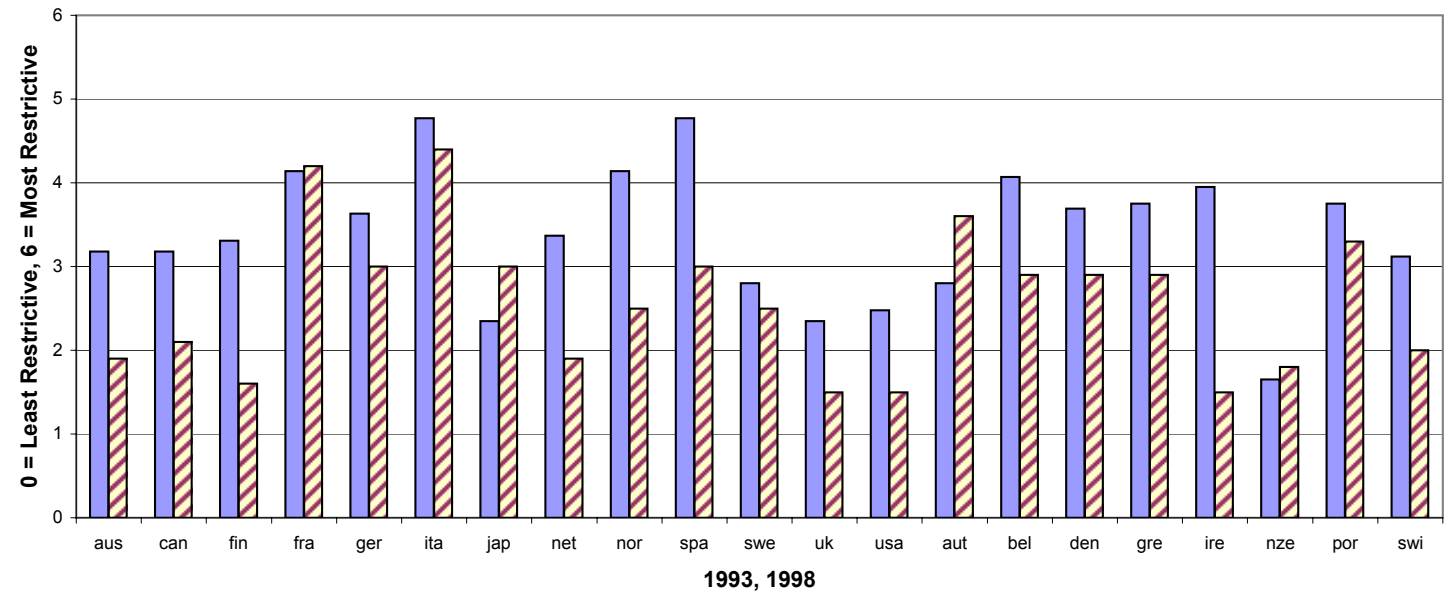

Regulatory Burdens, Index

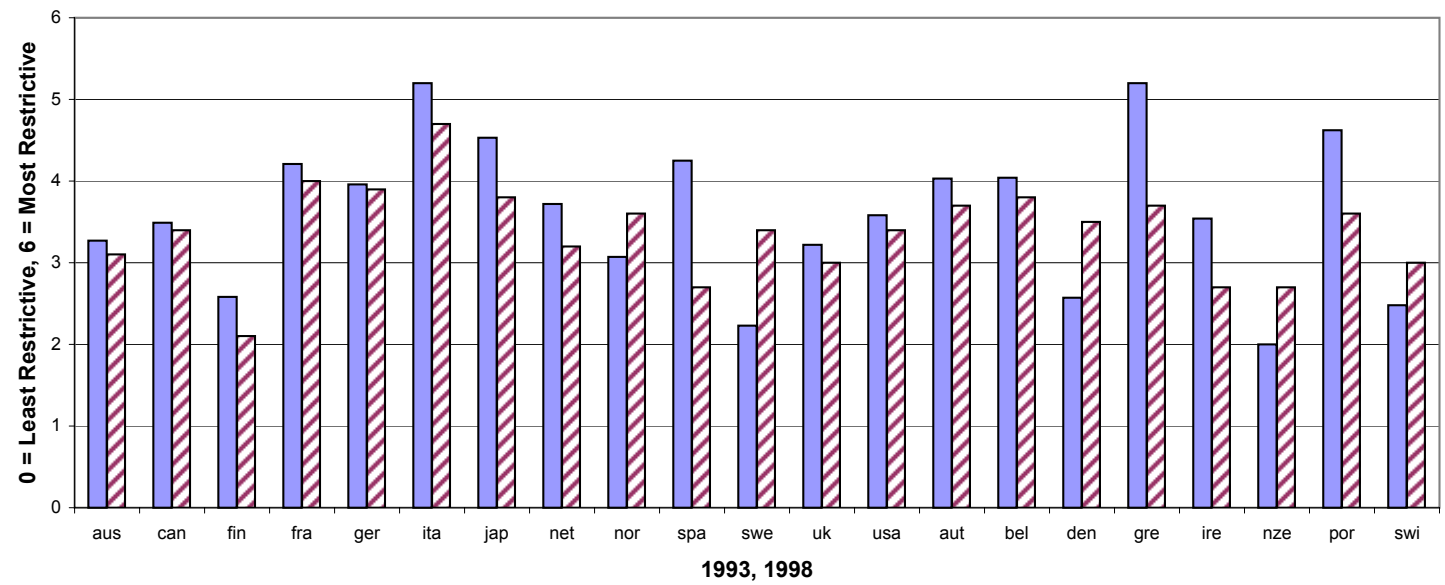




\section{Table $3^{1}$}

\section{Parameter Estimates for IT Expenditures Equation}

\begin{tabular}{|c|c|c|c|c|c|c|c|c|c|c|c|}
\hline & (1) & (2) & (3) & $(4)$ & (5) & (6) & (7) & $(8)$ & (9) & (10) & $(11)$ \\
\hline \multirow{2}{*}{ Constant $(\alpha)$} & -5.38 & -5.30 & -4.30 & -4.37 & -4.29 & -4.30 & -4.32 & -3.73 & -4.37 & -4.51 & -4.25 \\
\hline & 1.259 & 1.283 & 1.552 & 1.553 & 1.863 & 1.588 & 1.563 & 1.540 & 1.519 & 1.492 & 1.689 \\
\hline \multirow[t]{2}{*}{ Years of Schooling } & 0.29 & 0.26 & 0.26 & 0.25 & 0.25 & 0.26 & 0.25 & 0.27 & 0.28 & 0.26 & 0.26 \\
\hline & 0.045 & 0.038 & 0.041 & 0.040 & 0.048 & 0.043 & 0.047 & 0.043 & 0.053 & 0.041 & 0.047 \\
\hline Service Employment, & 0.10 & 0.10 & 0.09 & 0.10 & 0.09 & 0.09 & 0.09 & 0.09 & 0.10 & 0.09 & 0.09 \\
\hline Percent of Total & 0.016 & 0.018 & 0.019 & 0.018 & 0.020 & 0.019 & 0.020 & 0.016 & 0.021 & 0.020 & 0.020 \\
\hline \multirow[t]{2}{*}{ Regulatory Burdens, Index } & -0.24 & & -0.18 & -0.10 & -0.14 & -0.17 & -0.17 & -0.18 & -0.18 & -0.17 & -0.19 \\
\hline & 0.105 & & 0.115 & 0.140 & 0.153 & 0.120 & 0.125 & 0.116 & 0.112 & 0.115 & 0.140 \\
\hline Employment Protection & & -0.22 & -0.18 & -0.14 & -0.18 & -0.17 & -0.17 & -0.16 & -0.17 & -0.18 & -0.17 \\
\hline Legislation, Index & & 0.097 & 0.104 & 0.111 & 0.129 & 0.104 & 0.104 & 0.112 & 0.101 & 0.106 & 0.105 \\
\hline Regulatory Burdens on & & & & -0.12 & & & & & & & \\
\hline Startups, Index & & & & 0.107 & & & & & & & \\
\hline Stock Market Capitaliz- & & & & & 0.15 & & & & & & \\
\hline -ation, Percent of GDP & & & & & 0.224 & & & & & & \\
\hline \multirow[t]{2}{*}{ Real Interest Rate } & & & & & & -0.02 & & & & & \\
\hline & & & & & & 0.040 & & & & & \\
\hline Availability of Venture & & & & & & & 0.04 & & & & \\
\hline Capital, Index & & & & & & & 0.131 & & & & \\
\hline Investment, Percent of & & & & & & & & -0.02 & & & \\
\hline GDP & & & & & & & & 0.039 & & & \\
\hline \multirow[t]{2}{*}{ GDP per capita } & & & & & & & & & -0.01 & & \\
\hline & & & & & & & & & 0.023 & & \\
\hline \multirow[t]{2}{*}{ Trade Openness, Index } & & & & & & & & & & 0.04 & \\
\hline & & & & & & & & & & 0.092 & \\
\hline \multirow[t]{2}{*}{ Time Dummy } & & & & & & & & & & & -0.09 \\
\hline & & & & & & & & & & & 0.209 \\
\hline $\begin{array}{l}\text { Joint significance } \\
\text { Of regulatory variables }\end{array}$ & -- & -- & 0.023 & 0.027 & 0.066 & 0.032 & 0.043 & 0.041 & 0.013 & 0.026 & 0.005 \\
\hline Adjusted R-squared & 0.80 & 0.80 & 0.81 & 0.81 & 0.80 & 0.80 & 0.80 & 0.80 & 0.80 & 0.80 & 0.80 \\
\hline \# of Parameters & 4 & 4 & 5 & 6 & 6 & 6 & 6 & 6 & 6 & 6 & 6 \\
\hline
\end{tabular}


Table $4^{1}$

Parameter estimates for IT Expenditures Equation - Additional Results for Regulatory Burdens on Startups

\begin{tabular}{|c|c|c|c|c|c|c|c|c|c|c|c|}
\hline & $(1)$ & $(2)$ & (3) & $(4)$ & $(5)$ & $(6)$ & $(7)$ & $(8)$ & (9) & $(10)$ & $(11)$ \\
\hline \multirow[t]{2}{*}{ Constant $(\alpha)$} & -5.38 & -5.44 & -5.09 & -4.37 & -5.29 & -5.08 & -5.07 & -3.80 & -5.14 & -5.14 & -4.71 \\
\hline & 1.259 & 1.121 & 1.10 & 1.553 & 1.666 & 1.339 & 1.328 & 1.532 & 1.285 & 1.364 & 1.385 \\
\hline \multirow[t]{2}{*}{ Years of Schooling } & 0.29 & 0.26 & 0.27 & 0.25 & 0.27 & 0.26 & 0.27 & 0.28 & 0.30 & 0.27 & 0.27 \\
\hline & 0.045 & 0.042 & 0.042 & 0.040 & 0.050 & 0.044 & 0.046 & 0.044 & 0.053 & 0.041 & 0.042 \\
\hline Service Employment, & 0.10 & 0.11 & 0.10 & 0.10 & 0.10 & 0.10 & 0.10 & 0.09 & 0.11 & 0.10 & 0.10 \\
\hline Percent of Total & 0.016 & 0.015 & 0.016 & 0.018 & 0.016 & 0.016 & 0.017 & 0.016 & 0.017 & 0.016 & 0.017 \\
\hline \multirow[t]{2}{*}{ Regulatory Burdens, Index } & -0.24 & & -0.09 & -0.10 & -0.08 & -0.09 & -0.09 & -0.08 & -0.09 & -0.09 & -0.10 \\
\hline & 0.105 & & 0.136 & 0.140 & 0.150 & 0.138 & 0.133 & 0.146 & 0.136 & 0.138 & 0.126 \\
\hline Regulatory Burdens on & & -0.25 & -0.19 & -0.12 & -0.18 & -0.19 & -0.21 & -0.21 & -0.20 & -0.19 & -0.25 \\
\hline Startups, Index & & 0.079 & 0.105 & 0.107 & 0.185 & 0.109 & 0.109 & 0.111 & 0.106 & 0.106 & 0.104 \\
\hline Employment Protection & & & & -0.14 & & & & & & & \\
\hline Legislation, Index & & & & 0.111 & & & & & & & \\
\hline Stock Market Capitaliz- & & & & & 0.07 & & & & & & \\
\hline -ation, Percent of GDP & & & & & 0.304 & & & & & & \\
\hline \multirow[t]{2}{*}{ Real Interest Rate } & & & & & & -0.01 & & & & & \\
\hline & & & & & & 0.042 & & & & & \\
\hline Availability of Venture & & & & & & & -0.03 & & & & \\
\hline Capital, Index & & & & & & & 0.143 & & & & \\
\hline Investment, Percent of & & & & & & & & -0.04 & & & \\
\hline GDP & & & & & & & & 0.034 & & & \\
\hline \multirow[t]{2}{*}{ GDP per capita } & & & & & & & & & -0.02 & & \\
\hline & & & & & & & & & 0.022 & & \\
\hline \multirow[t]{2}{*}{ Trade Openness, Index } & & & & & & & & & & 0.01 & \\
\hline & & & & & & & & & & 0.089 & \\
\hline \multirow[t]{2}{*}{ Time Dummy } & & & & & & & & & & & -0.27 \\
\hline & & & & & & & & & & & 0.208 \\
\hline $\begin{array}{l}\text { Joint significance } \\
\text { of regulatory variables }\end{array}$ & $\overline{--}$ & -- & 0.014 & 0.027 & 0.135 & 0.028 & 0.025 & 0.009 & 0.003 & 0.015 & 0.005 \\
\hline Adjusted R-squared & 0.80 & 0.81 & 0.80 & 0.81 & 0.80 & 0.80 & 0.80 & 0.81 & 0.80 & 0.80 & 0.81 \\
\hline \# of Parameters & 4 & 4 & 5 & 6 & 6 & 6 & 6 & 6 & 6 & 6 & 6 \\
\hline
\end{tabular}


Table $5^{1}$

Parameter Estimates for Labor Productivity Growth Equation -- Alternative Formulations for Fixed Effects

\begin{tabular}{|c|c|c|c|c|}
\hline Lagged Regressors $^{2}$ & $\begin{array}{c}\text { Country \& } \\
\text { Year } \\
\text { Effects } \\
(1)\end{array}$ & $\begin{array}{c}\text { Country } \\
\text { Effects } \\
(2)\end{array}$ & $\begin{array}{c}\text { Year } \\
\text { Effects } \\
(3)\end{array}$ & $\begin{array}{c}\text { No Fixed } \\
\text { Effects } \\
(4)\end{array}$ \\
\hline \multirow[t]{2}{*}{ IT Production / GDP } & 0.896 & 1.071 & 0.256 & 0.263 \\
\hline & 0.412 & 0.374 & 0.327 & 0.327 \\
\hline \multirow[t]{2}{*}{ IT Spending / GDP } & 1.083 & 1.150 & 0.426 & 0.619 \\
\hline & 0.686 & 0.428 & 0.261 & 0.195 \\
\hline \multirow[t]{2}{*}{$\Delta$ (Employment / Pop) } & -0.695 & -0.786 & -0.676 & -0.691 \\
\hline & 0.141 & 0.112 & 0.149 & 0.101 \\
\hline $\begin{array}{l}\text { Joint significance } \\
\text { Of IT variables }{ }^{3}\end{array}$ & 0.007 & 0.000 & 0.028 & 0.002 \\
\hline SER(\%) & 1.081 & 1.059 & 1.197 & 1.189 \\
\hline Adjusted R-squared & 0.410 & 0.435 & 0.277 & 0.286 \\
\hline Log-likelihood & -142.674 & -144.817 & -160.467 & -163.53 \\
\hline \# Parameters & 23 & 16 & 11 & 4 \\
\hline Residual Independence ${ }^{4}$ & 0.980 & 0.803 & 0.015 & 0.017 \\
\hline
\end{tabular}

${ }^{1} \mathrm{For}$ the dependent variable, the sample mean is $2.14 \%$ and the sample standard deviation is $1.41 \%$.

${ }^{2}$ For each variable, top entry is point estimate and bottom entry is the Arellano (1987) heteroskedasticity-corrected standard error.

${ }^{3}$ Significance level needed to reject the null hypothesis that IT variables are jointly zero using a Wald test.

${ }^{4}$ Significance level needed to reject the null hypothesis that there is no correlation across periods and countries. See Doornik and Hendry (2001, page 94) for details. 


\section{Table $6^{1}$}

Generalized Least Squares (GLS) Parameter Estimates for Labor Productivity Growth Equation - Country Fixed Effects

\begin{tabular}{|c|c|c|c|}
\hline & GLS-1 ${ }^{2}$ & GLS-2 ${ }^{3}$ & OLS \\
\hline IT Production / GDP & $\begin{array}{l}0.906 \\
0.378\end{array}$ & $\begin{array}{l}0.947 \\
0.393\end{array}$ & $\begin{array}{l}1.071 \\
0.374\end{array}$ \\
\hline IT Expenditures / GDP & $\begin{array}{l}0.971 \\
0.258\end{array}$ & $\begin{array}{l}0.993 \\
0.276\end{array}$ & $\begin{array}{l}1.150 \\
0.422\end{array}$ \\
\hline$\Delta$ (Employment / Pop) & $\begin{array}{l}-0.731 \\
0.078\end{array}$ & $\begin{array}{r}-0.771 \\
0.074\end{array}$ & $\begin{array}{r}-0.786 \\
0.112\end{array}$ \\
\hline$\sigma_{E U}^{2}$, Variance, EU & $\begin{array}{c}1.0553 \\
0.179\end{array}$ & $\begin{array}{l}1.372 \\
0.286\end{array}$ & $\begin{array}{l}-- \\
--\end{array}$ \\
\hline$\theta_{\mathrm{EU}}$, Covariance, EU & $\begin{array}{l}0.046 \\
0.090\end{array}$ & $\begin{array}{l}0.104 \\
0.168\end{array}$ & $\begin{array}{l}-- \\
--\end{array}$ \\
\hline$\sigma_{\text {ROW, Variance, }}^{2}$ ROW & $\begin{array}{l}0.742 \\
0.188\end{array}$ & $\begin{array}{l}0.603 \\
0.116\end{array}$ & $\begin{array}{l}-- \\
--\end{array}$ \\
\hline $\begin{array}{l}\theta_{\text {Row, Covariance, }} \\
\text { ROW }\end{array}$ & $\begin{array}{l}-0.0628 \\
0.926\end{array}$ & $\begin{array}{l}-0.017 \\
0.042\end{array}$ & $\begin{array}{l}-- \\
--\end{array}$ \\
\hline $\begin{array}{c}\sigma^{2} \text { EU,ROW, Covariance, } \\
\text { EU-ROW }\end{array}$ & $\begin{array}{c}-0.112 \\
0.068\end{array}$ & $\begin{array}{l}-0.101 \\
0.066\end{array}$ & $\begin{array}{l}-- \\
--\end{array}$ \\
\hline $\begin{array}{l}\text { Joint Significance of } \\
\text { RegulatoryVariables }\end{array}$ & 0.000 & 0.000 & 0.000 \\
\hline Log-likelihood & -140.92 & -138.30 & -144.82 \\
\hline
\end{tabular}

${ }^{1}$ For each variable; top entry is point estimate and bottom entry is the standard error. For OLS, we report the Arallano (1987) heteroskedasticity-corrected standard error.

${ }^{2}$ For GLS-1, the European group includes Germany, France, Italy, the Netherlands, Spain, Finland, Sweden, Norway, and the United Kingdom. The ROW group is defined by the remaining countries.

${ }^{3}$ For GLS-2, the European group is defined by those countries participating in the European Monetary Union: Germany, France, Italy, the Netherlands, Spain, and Finland. The ROW group is defined by the remaining countries. ${ }^{4}$ Significance level needed to reject the null hypothesis that the regulatory variables are jointly zero using a Wald test. 
Table $7^{1}$

Parameter Estimates for IT Expenditures Using Instrumental Variables (IV)

\begin{tabular}{|c|c|c|c|c|}
\hline & IV & OLS & IV & OLS \\
\hline Constant & $\begin{array}{c}-4.42 \\
1.59\end{array}$ & $\begin{array}{l}-4.30 \\
1.55\end{array}$ & $\begin{array}{c}-4.25 \\
1.28\end{array}$ & $\begin{array}{c}-5.09 \\
1.10\end{array}$ \\
\hline Years of Schooling & $\begin{array}{l}0.28 \\
0.08\end{array}$ & $\begin{array}{l}0.26 \\
0.04\end{array}$ & $\begin{array}{l}0.18 \\
0.07\end{array}$ & $\begin{array}{l}0.27 \\
0.04\end{array}$ \\
\hline $\begin{array}{l}\text { Service Employment, } \\
\text { Percent of Total }\end{array}$ & $\begin{array}{l}0.10 \\
0.02\end{array}$ & $\begin{array}{l}0.09 \\
0.02\end{array}$ & $\begin{array}{l}0.10 \\
0.02\end{array}$ & $\begin{array}{l}0.10 \\
0.02\end{array}$ \\
\hline $\begin{array}{l}\text { Regulatory Burdens, } \\
\text { Index }\end{array}$ & $\begin{array}{l}-0.18 \\
0.11\end{array}$ & $\begin{array}{l}-0.18 \\
0.12\end{array}$ & $\begin{array}{l}0.20 \\
0.36\end{array}$ & $\begin{array}{l}-0.09 \\
0.14\end{array}$ \\
\hline $\begin{array}{l}\text { Employment Protection } \\
\text { Legislation, Index }\end{array}$ & $\begin{array}{l}-0.17 \\
0.11\end{array}$ & $\begin{array}{l}-0.18 \\
0.10\end{array}$ & & \\
\hline $\begin{array}{l}\text { Regulatory Burdens on } \\
\text { Startups, Index }\end{array}$ & & & $\begin{array}{l}-0.59 \\
0.44\end{array}$ & $\begin{array}{l}-0.19 \\
0.11\end{array}$ \\
\hline $\begin{array}{l}\text { Joint Significance of } \\
\text { RegulatoryVariables }^{2}\end{array}$ & 0.031 & 0.023 & 0.065 & 0.014 \\
\hline Adjusted R-squared & 0.81 & 0.81 & 0.75 & 0.80 \\
\hline
\end{tabular}


Table $8^{1}$

Parameter Estimates for IT Expenditures Using Generalized Least Squares (GLS)

\begin{tabular}{|c|c|c|c|c|}
\hline & GLS & OLS & GLS & OLS \\
\hline Constant & $\begin{array}{c}-4.33 \\
1.39\end{array}$ & $\begin{array}{c}-4.30 \\
1.55\end{array}$ & $\begin{array}{c}-5.59 \\
1.28\end{array}$ & $\begin{array}{c}-5.10 \\
1.10\end{array}$ \\
\hline Years of Schooling & $\begin{array}{l}0.25 \\
0.07\end{array}$ & $\begin{array}{l}0.26 \\
0.04\end{array}$ & $\begin{array}{l}0.26 \\
0.07\end{array}$ & $\begin{array}{l}0.27 \\
0.04\end{array}$ \\
\hline $\begin{array}{l}\text { Service Employment, } \\
\text { Percent of Total }\end{array}$ & $\begin{array}{l}0.10 \\
0.02\end{array}$ & $\begin{array}{l}0.09 \\
0.02\end{array}$ & $\begin{array}{l}0.11 \\
0.02\end{array}$ & $\begin{array}{l}0.10 \\
0.02\end{array}$ \\
\hline $\begin{array}{l}\text { Regulatory Burdens, } \\
\text { Index }\end{array}$ & $\begin{array}{l}-0.10 \\
0.10\end{array}$ & $\begin{array}{l}-0.18 \\
0.12\end{array}$ & $\begin{array}{c}-0.01 \\
0.14\end{array}$ & $\begin{array}{l}-0.09 \\
0.14\end{array}$ \\
\hline $\begin{array}{l}\text { Employment Protection } \\
\text { Legislation, Index }\end{array}$ & $\begin{array}{l}-0.21 \\
0.10\end{array}$ & $\begin{array}{l}-0.18 \\
0.10\end{array}$ & & \\
\hline $\begin{array}{l}\text { Regulatory Burdens on } \\
\text { Startups, Index }\end{array}$ & & & $\begin{array}{l}-0.17 \\
0.10\end{array}$ & $\begin{array}{l}-0.19 \\
0.11\end{array}$ \\
\hline$\rho$, Serial Correlation & $\begin{array}{l}0.39 \\
0.15\end{array}$ & $\begin{array}{l}-- \\
--\end{array}$ & $\begin{array}{l}0.37 \\
0.17\end{array}$ & $\begin{array}{l}-- \\
--\end{array}$ \\
\hline $\begin{array}{l}\text { Joint Significance of } \\
\text { RegulatoryVariables }^{2}\end{array}$ & 0.025 & 0.023 & 0.072 & 0.014 \\
\hline Log-likelihood & -29.10 & -31.89 & -30.07 & -32.33 \\
\hline
\end{tabular}


Table $9^{1}$

Parameter Estimates for Aggregate Investment and IT Expenditures

\begin{tabular}{|c|c|c|c|c|}
\hline & Investment & IT Exp. & Investment & IT Exp. \\
\hline Constant & $\begin{array}{c}27.65 \\
6.40\end{array}$ & $\begin{array}{c}-4.30 \\
1.55\end{array}$ & $\begin{array}{c}33.33 \\
6.29\end{array}$ & $\begin{array}{c}-5.10 \\
1.10\end{array}$ \\
\hline Years of Schooling & $\begin{array}{l}0.54 \\
0.30\end{array}$ & $\begin{array}{l}0.26 \\
0.04\end{array}$ & $\begin{array}{l}0.34 \\
0.27\end{array}$ & $\begin{array}{l}0.27 \\
0.04\end{array}$ \\
\hline $\begin{array}{l}\text { Service Employment, } \\
\text { Percent of Total }\end{array}$ & $\begin{array}{l}-0.22 \\
0.10\end{array}$ & $\begin{array}{l}0.09 \\
0.02\end{array}$ & $\begin{array}{l}-0.25 \\
0.09\end{array}$ & $\begin{array}{l}0.10 \\
0.02\end{array}$ \\
\hline $\begin{array}{l}\text { Regulatory Burdens, } \\
\text { Index }\end{array}$ & $\begin{array}{l}-0.31 \\
0.62\end{array}$ & $\begin{array}{l}-0.18 \\
0.12\end{array}$ & $\begin{array}{l}0.30 \\
0.91\end{array}$ & $\begin{array}{l}-0.09 \\
0.14\end{array}$ \\
\hline $\begin{array}{l}\text { Employment Protection } \\
\text { Legislation, Index }\end{array}$ & $\begin{array}{l}0.82 \\
0.53\end{array}$ & $\begin{array}{l}-0.18 \\
0.10\end{array}$ & & \\
\hline $\begin{array}{l}\text { Regulatory Burdens on } \\
\text { Startups, Index }\end{array}$ & & & $\begin{array}{l}-0.40 \\
0.73\end{array}$ & $\begin{array}{l}-0.19 \\
0.11\end{array}$ \\
\hline $\begin{array}{l}\text { Joint Significance of } \\
\text { RegulatoryVariables }^{2}\end{array}$ & 0.254 & 0.023 & 0.825 & 0.014 \\
\hline Adjusted R-squared & 0.15 & 0.81 & 0.10 & 0.81 \\
\hline
\end{tabular}


Figure 7: Steady State Growth Path for Two Economies
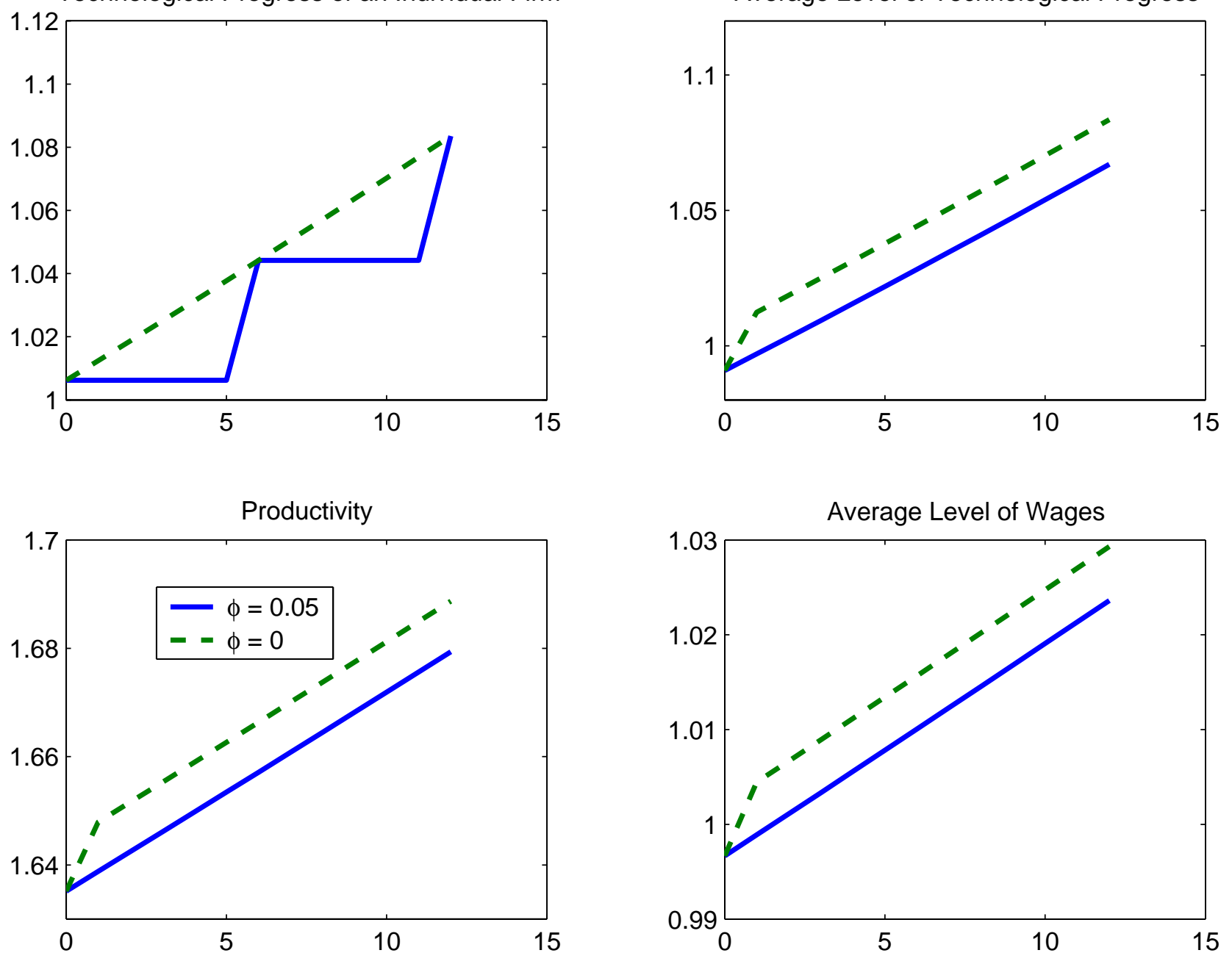